\title{
PENGARUH FAKTOR-FAKTOR PENARIK KEPARIWISATAAN WISATAWAN ASAL MALAYSIA TERHADAP KEPUTUSAN BERKUNJUNG KE KOTA PEKANBARU (Survei Pada Wisatawan Asal Malaysia yang Berkunjung ke Kota Peanbaru)
}

\author{
Mukiroh \\ HP. Diyah Setiyorini \\ Manajemen Pemasaran Pariwisata FPIPS UPI
}

\begin{abstract}
Pull factors tourists from Malaysia to visit Pekanbaru city in principle intended to be used by the government to develop tourism marketing strategies in increasing the number of tourist arrivals from Malaysia to Pekanbaru. Results of research conducted by using an explanatory survey of origin Malaysian tourist visiting Pekanbaru indicate that a visit to Pekanbaru city decision is influenced by a wide range of variables, availability of services, cultural, political stability and security, as well as the availability tourist attractions. The results of the analysis using 0:07\% error level indicates that these five variables, either as a whole or partially, a significant effect on decision to visit.
\end{abstract}

Keywords: Pull Factors and Decision to Visit.

\section{PENDAHULUAN}

\subsection{Latar Belakang Penelitian}

Perkembangan kepariwisataan di masa mendatang akan dihadapkan pada kompetisi yang semakin ketat, baik dalam aspek pemasaran maupun pengembangan produk. Kondisi tersebut akan terjadi di seluruh destinasi. Melihat berbagai kecenderungan tersebut, tantangan terbesar kepariwisataan Kota Pekanbaru adalah bagaimana menerapkan strategi yang tepat untuk dapat berkompetitif baik di lingkungan pariwisata regional maupun internasional. Hal ini dilatar belakangi oleh fakta merosotnya pertumbuhan kunjungan wisatawan ke Kota Pekanbaru beberapa tahun terakhir. Keadaan demikian menimbulkan prasangka apakah upaya yang dilaksanakan oleh Pemerintah kota Pekanbaru dalam meningkatkan kunjungan wisatawan asal Malaysia tidak berjalan atau kurang tepat. Dengan kata lain persepsi wisatwan asal malaysia tentang faktor-faktor penarik kepariwisataan di Kota Pekanbaru pada prinsipnya bertujuan agar dapat digunakan oleh pemerintah untuk menyusun strategi pemasaran pariwisata dalam meningkatkan jumlah kunjungan wisatawan asal Malaysia ke Kota Pekanbaru.

Wisatawan asal Malaysia merupakan pasar utama pariwisata Kota Pekanbaru. Hal ini dapat dilihat perkembangan jumlah kunjungan setiap tahun mengalami fluktuasi maka akan berpengaruh terhadap perolehan devisa daerah. Berikut ini dapat dilihat lima rangking utama wisatawan mancanegara yang berkunjung ke Kota Pekanbaru.

Tabel 1.1

\begin{tabular}{|l|c|c|}
\hline Negara & Rangking & Jumlah \\
\hline MALAYSIA & 1 & 10.435 \\
\hline SINGAPURA & 2 & 310 \\
\hline I N D I A & 3 & 228 \\
\hline U S A & 4 & 169 \\
\hline THAILAND & 5 & 130 \\
\hline
\end{tabular}

Lima Besar wisatawan Mancanegara ke Pekanbaru Tahun 2010

Sumber : Modifikasi Dinas Kebudayaan dan Pariwisata Provinsi Riau, 2011.

Berdasarkan Tabel 1.1 wisatawan asal Malaysia merupakan pasar utama pariwisata Kota Pekanbaru dengan sektor tertinggi 10.435 wisatawan di tahun 2010, kemudian disusul wisatawan Singapura, India, USA dan Thailand. Penentuan lima besar wisatawan mancanegara ke Kota Pekanbaru sekor dilihat berdasarkan jumlah kunjungan wisatawan diatas 100 orang ditahun 2010. Kota Pekanbaru memiliki potensi besar dalam meningkatkan jumlah kunjungan Wisatawan mancanegara terutama wisatawan asal malaysia. Melihat besarnya potensi wisatawan Asal Malaysia ke Kota Pekanbaru pemerintah Kota Pekanbaru menargetkan jumlah kunjungan wisatwan asal Malaysia ke Kota Pekanbaru sebesar 30 persen dari tahun sebelumnya. Namun pertumbuhan wisatawan 
Malaysia ke kota Pekanbaru dari tahun 20082010 mengalami penurunan setiap tahun, bahkan terjadi -,22 wisatawan malaysia di tahun 2007. Data tersebut dapat dilihat pada Tabel dibawah ini.

\section{TABEL 1.2 \\ PERTUMBUHAN WISATAWAN MALAYSIA KE KOTA PEKANBARU} TAHUN 2007-2010

\begin{tabular}{|c|c|c|}
\hline Tahun & Jumlah & Pertumbuhan \% \\
\hline 2006 & 9.803 & - \\
\hline 2007 & 7.652 & -22 \\
\hline 2008 & 9.261 & 21 \\
\hline 2009 & 10.336 & 12 \\
\hline 2010 & 10.435 & 1 \\
\hline
\end{tabular}

Sumber: modifikasi Dinas Kebudayaan dan Pariwisata Provinsi Riau 2011

Berdasarkan Tabel di atas, dapat dilihat bahwa pertumbuhan wisatawan asal Malaysia ke Kota Pekanbaru mengalami penurunan. Hal ini disayangkan karena Malaysia dan Kota Pekanbaru secara geografis memiliki posisi wilayah berdekatan, kesamaan budaya, dan kemiripan sejarah. Potensi ini merupakan kekuatan yang besar dan modal yang penting untuk menjalin kerjasama yang saling menguntungkan, jika dimanfaatkan secara baik.

Menurut Badan pariwisata daerah Riau Tourism Board (RTB) dalam riaubisnis.com, Rabu (25/8/2010) salah satu faktor yang menyebabkan turunnya pertumbuhan wisatawan asal Malaysia yang selama ini menjadi pasar pariwisata potensial Kota Pekanbaru yaitu memburuknya hubungan bilateral RI-Malaysia beberapa waktu terakhir. Hal ini dapat menyebabkan berkurangnya pendapatan daerah khususnya dari wisatawan asal Malaysia yang menjadi pasar utama Kota Pekanbaru.

Pemerintah Kota Pekanbaru harus berkomitmen dalam mengelola pasar tertentu yaitu wisatawan asal Malaysia yang sebagian besar berkunjung ke Kota Pekanbaru. Namun sampai saat ini belum terdapat data yang mencatat tentang perilaku wisatawan, khususnya pada persepsi wisatawan asal Malaysia tentang faktor-faktor yang menarik minat untuk berkunjung ke Kota Pekanbaru. Data hanya menunjukan jumlah kunjungan wisatawan. Padahal untuk membuat strategi pemasaran dibutuhkan data pendukung lainya, termasuk profil kebutuhan, dan persepsi wisatawan tentang faktor-faktor kepariwisataan destinasi.

Pemerintah kota Pekanbaru harus mengetahui kebutuhan dan keinginan wisatawan Malaysia, alasan datang, kegiatan apa saja yang disukai, dan persepsinya terhadap faktor-faktor yang menarik wisatawan Malaysia datang ke Kota Pekanbaru. Hal ini untuk membangun pariwisata Kota Pekanbaru dan dalam rangka memenangkan persaingan dengan menampilkan keunggulan daya tarik wisata yang dimiliki dalam memenuhi keinginan dan selera wisatawan Malaysia. Salah satu hal yang juga perlu diketahui adalah tentang persepsi wisatawan asal malaysia terhadap keberadaan destinasi di Kota Pekanbaru.

Berdasarkan latar belakang tersebut, maka perlu diadakan suatu penelitian tentang "Pengaruh Faktor-Faktor Penarik Kepariwisataan Wisatawan Asal Malaysia Terhadap Keputusan Berkunjung Ke Kota Pekanbaru"

\subsection{Rumusan Masalah}

Berdasarkan latar belakang di atas, maka rumusan penelitian ini sebagai berikut:

1. Bagaimana gambaran faktor-faktor penarik kepariwisataan wisatawan asal Malaysia untuk mengunjungi Kota Pekanbaru?

2. Bagaimana gambaran keputusan wisatawan asal Malaysia untuk mengunjungi Kota Pekanbaru?

3. Seberapa besar pengaruh dari faktor-faktor penarik kepariwisataan terhadap keputusan berkunjung Ke Kota Pekanbaru?.

\subsection{Tujuan dan Kegunaan Penelitian}

\subsubsection{Tujuan Penelitian}

1. Untuk memperoleh temuan tentang gambaran faktor-faktor penarik kepariwisataan wisatawan asal Malaysia untuk mengunjungi Kota Pekanbaru.

2. Untuk memperoleh temuan tentang gambaran keputusan wisatawan Malaysia untuk mengunjungi Kota Pekanbaru.

3. Untuk menperoleh temuan seberapa besar pengaruh faktor-faktor penarik kepariwisataan wisatawan asal Malaysia untuk menggunjungi Kota pekanbaru.

\subsubsection{Kegunaan Penelitian}

1. Kegunaan Teoritis 
Secara teoritis hasil penelitian ini diharapkan dapat menambah serta memperluas kajian ilmu pemasaran pariwisata, khususnya mengenai karakteristik wisatawan dan faktor-faktor penarik kepariwisataan wisatawan asal Malaysia untuk berkunjung ke kota pekanbaru serta Sebagai informasi dan bahan perbandingan bagi peneliti lain yang meneliti pada bidang usaha yang sama maupun khalayak umum untuk menambah pengetahuannya.

2. Kegunaan Praktis

Secara praktis hasil penelitian ini diharapkan dapat memberikan masukan bagi pemerintah Provinsi Riau khususnya dalam bidang pariwisata untuk pengembangan wisata Kota Pekanbaru mengenai Pengaruh faktor-faktor Penarik kepariwisataan wisatawan Asal Malaysia terhadap keputusan berkunjung ke Kota Pekanbaru sehingga dapat menjadi informasi bagi pihak terkait dalam upaya untuk meningkatkan jumlah kunjungan wisatawan Asal Malaysia di Kota Pekanbaru.

\section{KERANGKA PEMIKIRAN DAN} HIPOTESIS

\subsection{Kerangka Pemikiran}

Setiap orang mempunyai kebutuhan yang harus dipenuhi untuk memperoleh kepuasan. Kebutuhan yang sifatnya primer memang lebih diutamakan daripada kebutuhan yang sifatnya sekunder ataupun tersier. Tetapi tidak dapat dipungkiri bahwa setiap orang juga pasti mempunyai kebutuhan tersier. Salah satunya yaitu kebutuhan fisiologis yang lebih cenderung bersifat abstrak karena hanya dapat dirasakan dan tidak dapat dilihat orang lain. Salah satu kebutuhan fisiologis tersebut yaitu kebutuhan akan rekreasi.

Konsep Pemasaran adalah mengidentifikasi dan memenuhi kebutuhan sosial manusia. Pemasaran sebagai fungsi organisasi dan seperangkat proses untuk membuat, komunikasi dan nilai pemakaian pengiriman ke konsumen dan untuk mengelola hubungan dengan pelanggan dengan cara yang menguntungkan organisasi dan stakeholder. Kotler \& Lane (2009: 165).

Perspektif ekonomi dalam pariwisata yaitu segi permintaan (demand) dan penawaran (supply). Gunn dalam Ugy
Soebiyantoro (2009: 16) mendefinisikan pariwisata sebagai aktivitas ekonomi yang harus dilihat dari dua sisi yakni sisi permintaan (demand side) dan sisi pasokan/penawaran (supply side), lebih lanjut Gunn mengemukakan bahwa keberhasilan dalam pengembangan pariwisata di suatu daerah tergantung kepada kemampuan perencana dalam mengintegrasikan kedua sisi tersebut secara berimbang ke dalam sebuah rencana pengembangan pariwisata.

Kegiatan kepariwisataan dapat dilihat dari konteks sediaan dan permintaan yang merupakan komponen pasar kepariwisataan (Murphy, 1985 : 10). Sediaan adalah segala sesuatu dikonsumsi atau dinikmati oleh wisatawan yang dibentuk oleh berbagai faktor yang kemudian hasilnya dapat dikatakan sebagai produk wisata. Sedangkan permintaan adalah wisatawan dan segala sesuatu yang melekat pada diri wisatawan yang ditimbulkan oleh berbagai faktor yang kemudian membentuk apa yang disebut dengan citra wisata. ( Murphy, 1985 : 10).

Sisi permintaan meliputi minat dan kemampuan penduduk untuk berwisata yang dipengaruhi oleh karakteristiknya. Permintaan terhadap produk wisata merupakan fungsi dari kecenderungan dan hambatan untuk membeli produk wisata. Kecenderungannnya dipengaruhi faktor psikografis dan faktor demografis (status sosial ekonomi), dan faktor - faktor yang dapat menghambat adalah jarak, ekonomi, budaya, pelayanan, kualitas pelayanan, musim. (Yoeti, $1997: 87$ - 92).

Permintaan pariwisata adalah jumlah total dari orang yang melakukan perjalanan untuk menggunakan fasilitas dan pelayanan wisata di tempat yang jauh dari tempat tinggal dan tempat kerja Mathieson dan Wall dalam Indra Mulyana, (2009).

Suwardjoko (2007: 22) menyebutkan komponen permintaan terdiri atas elemen orang, ditenggarai oleh hasrat orang orang melakukan perjalanan dan kemampuan melakukanya, sedangkan sediaan (supply) adalah daya tarik wisata, serta perangkutan, informasi dan promosi, dan pelayanan. Murphy juga mengklasifikasikan komponenkomponen produk wisata atas fasilitas, aksesibilitas, dan infrastruktur.

Komponen pasar pariwisata yang dikemukakan Murphy (1985), yang dimaksud dengan sediaan adalah pengalaman, modal, 
dan sumberdaya yang dapat ditawarkan, dapat disebut sebagai produk wisata. Sedangkan yang dimaksud dengan permintaan adalah motivasi, persepsi, dan harapan seseorang terhadap sesuatu yang dapat dinikmati dan dirasakan, dapat disebut sebagai citra wisata. Menurut Kotler \& Koltler (2009: 178) motivasi, persepsi, pembelajaran dan memori merupakan bagian dari faktor-faktor psikologi.

Persepsi merupakan salah satu faktor psikologis yang mempengaruhi bentuk perilaku konsumen terhadap permintaan pariwisata, Persepsi mengambarkan bagaimana individu-individu mengambil keputusan atau membuat pilihan dari dua alternatif atau lebih, dan bagaimana kualitas pilihan terakhir. Definisi perspsi adalah: “ Proses dimana konsumen memilih, mengatur dan menginterpretasikan informasi untuk membentuk gambaran yang berarti mengenai dunia”. Kotler (2009: 179).

Sehubungan dengan definisi tersebut, persepsi juga berkaitan dengan permintaan pariwisata. Adapun permintaan pariwisata dipengaruhi oleh faktor penarik dan pendorong. Faktor pendorong mengambarkan bagaimana seseorang turis didorong oleh berbagai macam motivasi dan persepsi yang berkaitan erat dengan pengambilan keputusan untuk berpergian. Sedangkan faktor penarik menjelaskan bagaimana wisatawan tertarik dengan sebuah destinasi, Weaver \& Lowton dalam Giva Pavule (2006: 27). Kedua faktor tersebut saling berkaitan, dengan demikian pemasar perlu memahami pula persepsi wisatawan terhadap faktor-faktor penarik di suatu destinasi.

Menurut Weaver \& Lowton dalam Giva Pavule (2006:27) faktor penarik didefinisikan sebagai sesuatu kekuatan yang dapat membantu untuk merangsang sebuah produk wisata dengan menarik konsumen kepada suatu destinasi tertentu

Sub faktor yang termasuk dalam faktor penarik adalah:

a. Aksesibilitas.

Sarana dan infrastuktur yang baik seperti transportasi, telepon umum, ketertiban jalan raya, trotoar untuk pejalan kaki dan lain-lain dapat menjadi faktor penarik utama bagi wisatawan dalam memilih negara destinasi.

b. Ketersediaan jasa atau service.
Kesuksesan suatu produk pariwisata seringkali bergantung pada ketersedian atas fasilitas-fasilitas jasa, seperti akomodasi, makanan dan minuman, travel agency, Souvenir, iklan media masa dan lain-lain.

c. Budaya.

Berdasarkan Mc Intosh, salah satu dari empat motivasi berpergian adalah budaya, yang berarti keinginan untuk memperoleh keinginan untuk memperoleh pengetahuan negara lain, seperti musik, seni, tari, cerita rakyat dan agama. Sedangkan Ross dalam Giva Pavule (2006:27) berpendapat wisatawan ingin mencari pengalaman lain dalam hal budaya yang mana berhubungan dengan budaya mereka sendiri.

d. Stabilitas politik dan keamanan.

Stabilitas politik dan keamanan suatu daerah atau negara merupakan salah satu faktor yang berpengaruh terhadap pemilihan negara destinasi.

e. Ketersediaannya atraksi.

Kemampuan suatu destinasi untuk menarik konsumen bergantung oleh beberapa faktor, seperti kualitas, kuantitas, keanekaragaman, keunikan dari suatu atraksi atau hiburan dalam Weaver \& Lowton dalam Pavule Giva (2006: 27). Ketersedian suatu atraksi merupakan bagian yang vital untuk menciptakan permintaan pariwisata karena atraksi-atraksi adalah suatu produk yang di jual kepada pengunjung.

Wisatawan membuat keputusan bertindak didasari saat melakukan kunjungan di tempat asal maupun saat memilih lokasi wisata dan semuanya didasari oleh motivasi wisatawan saat berkunjung ke suatu tempat.

Motivasi merupakan kebutuhan dan keinginan yang merupakan faktor pendorong untuk melakukan perjalanan. Sedangkan keputusan berkunjung wisatawan yaitu bagaimana wisatwan memandang suatu masalah atau kebutuhan dan bagaimana motivasi yang muncul dalam dirinya (Morrisan, 2007: 68).

Medlik dalam Ariyanto (2005), menyatakan ada lima faktor yang menentukan seseorang untuk membeli jasa atau mengunjungi objek wisata, yaitu:

1. Lokasi. 
Dari segi lokasi ini, pembeli akan memilih lokasi yang benar-benar strategis dan tidak membutuhkan terlalu banyak waktu, tenaga, dan biaya seperti: mudah dijangkau, dekat dengan fasilitas-fasilitas umum, atau mungkin dekat dengan jalan raya, sehingga lokasi ini dapat mendukung yang lain. Medlik dalam Ariyanto (2005).

2. Fasilitas.

Fasilitas fungsinya adalah memenuhi kebutuhan wisatawan selama tinggal untuk sementara waktu di DTW yang dikunjungi. Termasuk dalam kelompok ini menurut Victor T.C. Milddelton dalam Yoeti (2005: 4) adalah Accomondation Units, Restoran, Bars dan café, Transportation at the destination, sport and aktivitis, others facilities, Retail outlets, others services. Medlik dalam Ariyanto (2005)

3. Citra/image.

Setiap daerah tujuan wisata mepunyai citra (image) tertentu yaitu mental map seseorang terhadap suatu destnasi yang mengandung kenyakinan, kesan dan persepsi. Citra yang terbentuk dipasar merupakan kombinasi antara berbagai faktor yang ada pada destinasi yang bersangkutan (seperti cuaca, pemandanan alam, keamanan, kesehatan dan sanitasi, keramah tamahan, dan lain-lain) disatu fihak dan informasi yang diterima oleh calon wisatawan dari berbagai sumber di fihak lain, atau fantasinya sendiri, walaupun tidak real, sangat penting didalam mempengaruhi keputusan calon wisatawan, Medlik dalam Ariyanto (2005).

4. Harga/tarif.

Harga yang tinggi pada suatu daerah tujuan wisata maka akan memberikan imbas/timbal balik pada wisatawan yang akan bepergian/calon wisata, sehingga permintaan wisatapun akan berkurang begitupula sebaliknya. Medlik 1980 dalam Ariyanto (2005).

5. Pelayanan.

Bagi konsumen yang ingin membeli suatu produk, pelayanan yang diberikan pada saat memilih sampai terjadinya transaksi pembelian sangatlah berpengaruh terhadap jadi tidaknya pembelian yang dilakukan oleh konsumen. Pelayanan yang kurang baik akan menimbulkan rasa tidak puas yang dirasakan oleh konsumen yang selanjutnya akan mempengaruhi tingkat penjualan pada waktu selanjutnya. Medlik dalam Ariyanto (2005)

Wisatawan dalam mengunjungi suatu daerah pasti melakukan kegiatan transaksi wisata. Biasanya wisatawan melaksanakan transaksi wisata pada saat mereka berkunjung.

Sebelum memproduksi sebuah produk/jasa suatu perusahaan/ pemerintah harus memperhatikan bagaimana peranan keputusan berkunjung yang dimainkan konsumen agar perusahaan tersebut dapat merancang produk/jasa sesuai dengan kebutuhan dan keinginan wisatawan, menentukan pasar mana yang menjadi sasaran dan dapat memperkirakan berapa biaya promosi untuk produk tersebut sehingga tidak melebihi anggaran yang ada.

Berdasarkan teori yang telah diungkap oleh beberapa ahli diatas maka motivasi dan persepsi wisatawan merupakan faktor utama yang penarik wisatawaan untuk melakukan perjalanan wisata atau keputusan berkunjung ke daya tarik wisata yang terdapat pada suatu tempat, daerah, provinsi dan negara. Secara teoritis faktor-faktor penarik yang terdiri Aksesibilitas, Ketersediaan jasa atau service Budaya, Stabilitas politik dan keamanan. Ketersediaan atraksi mempunyai pengaruh positif terhadap keputusan berkunjung wisatawan.

Keterkaitan antara ke dua konsep di atas merupakan kerangka pemikiran yang dijadikan landasan penelitian sebagaimana terlihat pada Gambar 2.1 berikut:

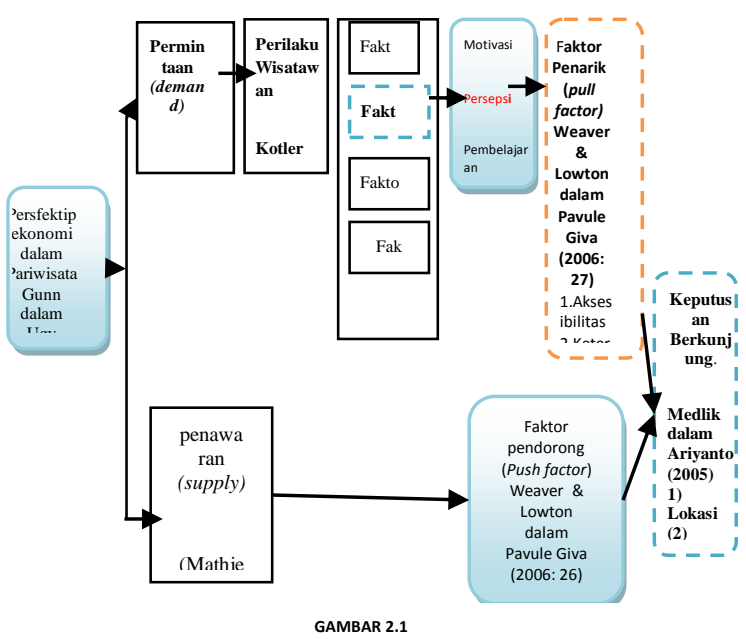

PENGARUH FAKTOR-FAKTOR PENARIK KEPARIWISATAAN WISATAWAN ASAL MALAYSIA

\subsection{HIPOTESIS.}


Suharsimi Arikunto (2009: 67) mengemukakan hipotesis sebagai suatu jawaban sementara terhadap permasalahan penelitian sampai terbukti melalui data yang terkumpul.

Sugiono (2009: 38) mengemukakan bahwa hipotesis merupakan jawaban sementara terhadap masalah penelitian yang dibangun berdasarkan kerangka teoritis yang kebenaranya perlu diuji secara empiris.

Penelitian dalam menyusun hipotesis didukung oleh beberapa premis yang menyatakan pengaruh faktor-faktor penarik kepariwisataan wisatawan asal Malaysia terhadap keputusan berkunjung di Kota Pekanbaru, sebagai berikut:

1. Kotler \& Lane (2009: 189).

Prilaku wisatawan merupakan suatu kebutuhan dan keinginan wisatawan baik itu berupa jasa, ide-de, atau pengalaman yang mampu memuaskan keinginan dan kebutuhan wisatawan yang dilakukan oleh pemasar atau perusahaan

2. Motivasi merupakan kebutuhan dan keinginan yang merupakan faktor pendorong untuk melakukan perjalanan. Sedangkan keputusan berkunjung oleh wisatawan bagaimana wisatawan memandang suatu masalah atau kebutuhan dan bagaimana motivasi yang muncul dalam dirinya. (Morrisan, 2007: 68).

3. Menurut Kotler dan Lane (2009: 200)

Kombinasi faktor psikologi dengan karakteristik keyakinan wisatawan mampu mengkasifikasikan proses keputusan dan keputusan berkunjung.

4. Menurut Vellas (2008: 101)

Faktor penarik adalah Faktor yang menarik orang untuk membeli suatu produk, misalnya ciri khusus suatu destinasi atau memotivasi berbagai tipe orang untuk berkunjung ketempat tersebut.

Berdasarkan premis-premis tersebut, maka hipotesis dalam penelitian ini adalah: "Terdapat pengaruh yang signifikan antara faktor-faktor penarik kepariwisataan wisatawan asal Malaysia terhadap keputusan berkunjung ke Kota Pekanbaru".
III. OBJEK DAN METODE

PENELITIAN

\subsection{Objek penelitian}

Penelitian ini menganalisis variabel bebas atau independent variable dan variabel terikat dependent variable, dalam penelitian ini yang menjadi variabel bebas adalah faktorfaktor penarik sebagai $\mathrm{X}$ (independen) yang terdiri dari $\left(\mathrm{X}_{1.1}\right)$ Aksesibilitas, $\left(\mathrm{X}_{1.2}\right)$ Ketersediaan jasa atau service, $\left(\mathrm{X}_{1.3}\right)$ budaya, $\left(\mathrm{X}_{1.4}\right)$ Stabilitas politik dan keamanan, $\left(\mathrm{X}_{1.5}\right)$ Ketersediaannya atraksi sedangkan keputusan berkunjung sebagai $\mathrm{Y}$ yang merupakan variabel tidak bebas (dependen) yang terdiri dari Lokasi, Fasilitas, Citra/ image, Harga/tariff, dan Pelayanan.

Objek penelitian ini adalah pendapat responden tentang Pengaruh Faktor-faktor Penarik kepariwisataan wisatawan asal Malaysia terhadap Keputusan Berkunjung ke Kota Pekanbaru, sedangkan subjek penelitian ini adalah wisatawan asal Malaysia yang berkunjung ke Kota Pekanbaru.

Pelaksanaan penelitian ini berlangsung selama kurun waktu kurang dari satu tahun, maka metode yang digunakan pada penelitian ini adalah metode cross sectional. Cross Sectional Method adalah metode penelitian dengan cara mempelajari objek dalam satu kurun waktu saja (tidak berkesinambungan dalam jangka waktu panjang). (Husein Umar, 2009:45).

\subsection{Metode Penelitian}

Metode penelitian dapat diartikan sebagai suatu cara kerja untuk mencapai tujuan tertentu, agar dapat terkumpul data serta dapat mencapai tujuan penelitian itu sendiri, sedangkan menurut Sugiyono (2008:5) metode penelitian dapat diartikan sebagai cara ilmiah, yang dilakukan untuk mendapatkan data yang objektif, valid dan reliabel, dengan tujuan dapat ditemukan, dibuktikan, dan dikembangkan suatu pengetahuan untuk memahami, memecahkan dan mengantisipasi masalah.

\subsubsection{Jenis Penelitian dan Metode yang Digunakan}

Berdasarkan variabel-variabel yang diteliti maka jenis penelitian dari penelitian ini adalah penelitian deskriptif dan verifikatif. Menurut pendapat Sugiyono (2008:11) mengemukakan bahwa metode penelitian 
deskritiptif adalah penelitian yang dilakukan untuk mengetahui nilai variabel mandiri, baik satu variabel atau lebih tanpa membuat perbandingan, atau menghubungkan antara variabel satu dengan yang lain. Melalui penelitian deskriptif ini, maka dapat diperoleh gambaran mengenai faktor-faktor penarik (X) yang memiliki lima sub variabel yaitu dari $\left(\mathrm{X}_{1.1}\right)$ Aksesibilitas, $\left(\mathrm{X}_{1.2}\right)$ Ketersediaan jasa atau service, $\left(\mathrm{X}_{1.3}\right)$ budaya , $\left(\mathrm{X}_{1.4}\right)$ Stabilitas politik dan keamanan, $\left(\mathrm{X}_{1.5}\right)$ Ketersediaannya atraksi, kemudian objek penelitian yang menjadi variabel terikat adalah keputusan berkunjung $(\mathrm{Y})$ sebagai variabel terikat yang memiliki sub variabel Lokasi, Fasilitas, Citra/ image, Harga/tariff, dan Pelayanan.

Sifat verifikatif pada dasarnya ingin menguji kebenaran dari suatu hipotesis yang dilaksanakan melalui pengumpulan data dilapangan, dalam hal ini penelitian verifikatif bertujuan untuk mengetahui pengaruh faktorfaktor penarik kepariwisataan wisatawan terhadap keputusan berkunjung, berdasarkan jenis penelitiannya yaitu penelitian deskriptif dan verifikatif maka metode yang digunakan dalam penelitian ini adalah survey explanatory.

Berdasarkan jenis penelitian tersebut digunakan metode informasi dari sebagian populasi dikumpulkan langsung ditempat kejadian dengan tujuan untuk mengetahui pendapat dari sebagian populasi terhadap objek yang sedang diteliti.

Penelitian ini dilakukan dalam kurun waktu kurang dari satu tahun, yaitu mulai dari bulan Agustus 2011 sampai dengan bulan Oktober 2011, maka pendekatan yang digunakan menurut Sugiyono (2008:8) Cross sectional method adalah metode penelitian yang mempelajari objek dalam kurun waktu tertentu (tidak berkesinambungan dalam jangka waktu panjang).

\subsubsection{Operasionalisasi Variabel Penelitian}

Penelitian ini meliputi dua variabel inti, yaitu variabel bebas dan variabel terikat. Menurut Asep Hermawan (2006:53), yang dimaksud dengan variabel bebas (independent variable) adalah variabel yang mempengaruhi variabel terikat secara positif maupun negatif. Variabel terikat (dependent variable) merupakan variabel yang dipengaruhi oleh variabel bebas.

Variabel yang diteliti pada penelitian ini adalah mengenai faktor-faktor penarik (X) yang memiliki lima sub variabel yaitu $\left(\mathrm{X}_{1.1}\right)$ $\left(\mathrm{X}_{1.1}\right)$ Aksesibilitas, $\left(\mathrm{X}_{1.2}\right)$ Ketersediaan jasa atau service, $\left(\mathrm{X}_{1.3}\right)$ budaya , $\left(\mathrm{X}_{1.4}\right)$ Stabilitas politik dan keamanan, $\left(\mathrm{X}_{1.5}\right)$ kemudian objek penelitian yang menjadi variabel terikat (dependent variabel) adalah keputusan berkunjung (Y) yang memiliki sub variabel Lokasi, Fasilitas, Citra/ image, Harga/tariff, dan Pelayanan.

Pengoperasian variabel dari kedua variabel yang dijadikan objek pada penelitian ini menggunakan skala ordinal. Operasionalisasi variabel penelitian disajikan pada Tabel 3.1

TABEL 3.1

OPERASIONALISASI VARIABEL

\begin{tabular}{|c|c|c|c|c|c|}
\hline $\begin{array}{c}\text { Variabel/Sub } \\
\text { Variabel } \\
\end{array}$ & $\begin{array}{c}\text { Konsep } \\
\text { Variabel } \\
\end{array}$ & Indikator & Ukuran & Skala & No.Item \\
\hline 1 & 2 & 3 & 4 & 5 & 6 \\
\hline $\begin{array}{l}\text { Faktor-faktor } \\
\text { penarik } \\
\text { (X) }\end{array}$ & \multicolumn{5}{|c|}{$\begin{array}{l}\text { faktor penarik didefinisikan sebagai sesuatu kekuatan yang dapat membantu } \\
\text { untuk merangsang sebuah produk wisata dengan menarik konsumen kepada suatu } \\
\text { destinasi tertentu. Giva Pavule (2006:27). }\end{array}$} \\
\hline Aksesibilitas(X1) & $\begin{array}{l}\text { Sarana dan } \\
\text { infrastuktur yang } \\
\text { baik seperti } \\
\text { transportasi, } \\
\text { telepon umum, } \\
\text { ketertiban jalan } \\
\text { raya, trotoar }\end{array}$ & $\begin{array}{l}\text { Sarana angkutan } \\
\text { menuju daya } \\
\text { tarik wisata di } \\
\text { Kota Pekanbaru. } \\
\text { Kondisi jalan } \\
\text { menuju daya } \\
\text { tarik wisata di }\end{array}$ & $\begin{array}{l}\text { - } \text { Tingkat } \\
\text { Kemudahan } \\
\text { sarana } \\
\text { angkutan } \\
\text { menuju } \\
\text { daya tarik } \\
\text { wisata di }\end{array}$ & Ordinal & III.A.1. \\
\hline
\end{tabular}




\begin{tabular}{|c|c|c|c|c|c|}
\hline & $\begin{array}{l}\text { untuk pejalan } \\
\text { kaki dan lain- } \\
\text { lain dapat } \\
\text { menjadi faktor } \\
\text { penarik utama } \\
\text { bagi wisatawan } \\
\text { dalam memilih } \\
\text { negara destinasi. } \\
\text { Giva Pavule } \\
(2006: 27) \text {. }\end{array}$ & $\begin{array}{l}\text { Kota Pekanbaru. } \\
\text { Tersedianya } \\
\text { sarana } \\
\text { komunikasi } \\
\text { pariwisata di } \\
\text { Kota } \\
\text { Pekanbaru. } \\
\text { Kelayakan } \\
\text { sarana } \\
\text { komunikasi } \\
\text { pariwisata di } \\
\text { Kota } \\
\text { Pekanbaru. } \\
\text { Tersedianya } \\
\text { petunjuk jalan } \\
\text { menuju objek } \\
\text { wisata. } \\
\text { Kemudahan } \\
\text { pelayanan dari } \\
\text { imigrasi }\end{array}$ & $\begin{array}{l}\text { Kota } \\
\text { Pekanbaru. } \\
\text { Tingkat } \\
\text { Kelayakan } \\
\text { kondisi } \\
\text { jalan } \\
\text { menuju } \\
\text { daya tarik } \\
\text { wisata di } \\
\text { Kota } \\
\text { Pekanbaru. } \\
\text { Tingkat } \\
\text { Tersediany } \\
\text { a sarana } \\
\text { komunikas } \\
\text { i } \\
\text { pariwisata } \\
\text { di Kota } \\
\text { Pekanbaru. } \\
\text { Tingkat } \\
\text { Kelayakan } \\
\text { sarana } \\
\text { komunikas } \\
\text { i } \\
\text { pariwisata } \\
\text { di Kota } \\
\text { Pekanbaru. } \\
\text { Tingkat } \\
\text { Tersediany } \\
\text { a petunjuk } \\
\text { jalan } \\
\text { menuju } \\
\text { objek } \\
\text { wisata. } \\
\text { Tingkat } \\
\text { Kemudahan } \\
\text { pelayanan } \\
\text { dari } \\
\text { imigrasi } \\
\end{array}$ & & $\begin{array}{l}\text { III.A.5 } \\
\text { III.A.6 }\end{array}$ \\
\hline $\begin{array}{l}\text { Ketersediaan jasa } \\
\text { atau service } \\
\text { (X2) }\end{array}$ & $\begin{array}{l}\text { Sebagian besar } \\
\text { wisatawan } \\
\text { sangat } \\
\text { membutuhkan } \\
\text { pelayanan seperti } \\
\text { akes transporasi } \\
\text { yang baik, } \\
\text { akomodasi, toilet } \\
\text { dan makanan. } \\
\text { Giva Pavule } \\
(2006: 27) \text {. }\end{array}$ & $\begin{array}{ll}\text { - } & \text { Tersedianya } \\
\text { Pemandu wisata } \\
\text { di Kota } \\
\text { Pekanbaru } \\
\text { - } \\
\text { Pelayanan } \\
\text { rumah makan di } \\
\text { Kota Pekanbaru } \\
\text { - Pelayanan Hotel } \\
\text { di Pekanbaru. } \\
\text { Pelayanan } \\
\text { fasilitas umum } \\
\text { seperti toilet di } \\
\text { Kota pekanbaru. }\end{array}$ & $\begin{array}{l}\text { - Tingkat } \\
\text { tersedianya } \\
\text { pemandu } \\
\text { wisata di } \\
\text { Kota } \\
\text { Pekanbaru. } \\
\text { Tingkat } \\
\text { Pelayanan } \\
\text { rumah } \\
\text { makan di } \\
\text { Kota } \\
\text { Pekabaru. } \\
\text { Tingkat } \\
\text { Pelayanan }\end{array}$ & Ordinal & $\begin{array}{l}\text { A.II.7 } \\
\text { A.II.8 } \\
\text { A.II.9 } \\
\text { A.II.10 }\end{array}$ \\
\hline
\end{tabular}




\begin{tabular}{|c|c|c|c|c|c|}
\hline & & & $\begin{array}{l}\text { Hotel di } \\
\text { Kota } \\
\text { Pekanbaru. } \\
\text { Tingkat } \\
\text { ketersedian } \\
\text { pelayanan } \\
\text { fasilitas } \\
\text { umum } \\
\text { seperti toilet } \\
\text { di Kota } \\
\text { Pekanbaru. }\end{array}$ & & \\
\hline Budaya (X3) & $\begin{array}{l}\text { Kesamaan } \\
\text { budaya, bahasa } \\
\text { dan agama dapat } \\
\text { menjadi faktor } \\
\text { penarik } \\
\text { wisatatawan } \\
\text { dalam memilih } \\
\text { daerah tujuan } \\
\text { wisata. } \\
\text { Giva Pavule } \\
(2006: 27)\end{array}$ & $\begin{array}{ll}\text { Daya tarik } \\
\text { kesamaan } \\
\text { budaya } \\
\text { Daya tarik } \\
\text { atraksi budaya } \\
\text { seperti } \\
\text { bangunan } \\
\text { bersejarah di } \\
\text { Kota Pekanbaru. } \\
\text { Keunikan } \\
\text { atraksi budaya } \\
\text { seperti } \\
\text { bangunan } \\
\text { bersejarah di } \\
\text { Kota Pekanbaru }\end{array}$ & $\begin{array}{ll}\text { - } & \text { Tingkat } \\
\text { daya tarik } \\
\text { kesamaan } \\
\text { budaya } \\
\text { Pekanbaru. } \\
\text { Tingkat } \\
\text { daya tarik } \\
\text { budaya } \\
\text { seperti } \\
\text { bangunan } \\
\text { bersejarah di } \\
\text { Kota } \\
\text { Pekanbaru. } \\
\text { Tingkat } \\
\text { Keunikan } \\
\text { atraksi } \\
\text { budaya } \\
\text { seperti } \\
\text { bangunan } \\
\text { bersejarah di } \\
\text { Kota } \\
\text { Pekanbaru. }\end{array}$ & Ordinal & $\begin{array}{l}\text { A.II.11 } \\
\text { A.II.12 }\end{array}$ \\
\hline $\begin{array}{l}\text { Stabilitas politik } \\
\text { dan keamanan } \\
\text { (X4) }\end{array}$ & $\begin{array}{l}\text { Stabilitas politik } \\
\text { dan keamanan } \\
\text { suatu daerah atau } \\
\text { negara } \\
\text { merupakan } \\
\text { salah satu faktor } \\
\text { yang } \\
\text { berpengaruh } \\
\text { terhadap } \\
\text { pemilihan } \\
\text { Negara destinasi. } \\
\text { Giva Pavule } \\
(2006: 27) .\end{array}$ & $\begin{array}{l}\text { Keamanan saat } \\
\text { perjalanan } \\
\text { menuju daya } \\
\text { tarik wisata di } \\
\text { Kota Pekanbaru. } \\
\text { Keamana saat } \\
\text { berada di daya } \\
\text { tarik wisata di } \\
\text { Kota Pekanbaru. }\end{array}$ & 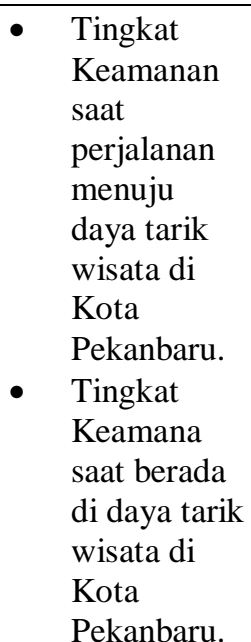 & Ordinal & A.II.14 \\
\hline $\begin{array}{l}\text { Ketersediaan-nya } \\
\text { atraksi } \\
\quad \text { (X5) }\end{array}$ & $\begin{array}{l}\text { Kemampuan } \\
\text { suatu destinasi } \\
\text { untuk menarik } \\
\text { konsumen }\end{array}$ & $\begin{array}{ll}\text { - } & \text { Daya tarik } \\
\text { wisata alam di } \\
\text { Kota Pekanbaru. } \\
\text { - } \quad \text { Keragaman }\end{array}$ & $\begin{array}{ll}\text { - } & \text { Tingkat } \\
\text { Daya tarik } \\
\text { wisata alam } \\
\text { di Kota }\end{array}$ & Ordinal & A.II.16 \\
\hline
\end{tabular}




\begin{tabular}{|c|c|c|c|c|c|}
\hline & $\begin{array}{l}\text { bergantung oleh } \\
\text { beberapa faktor, } \\
\text { seperti kualitas, } \\
\text { kuantitas, } \\
\text { keanekaragaman, } \\
\text { keunikan dari } \\
\text { suatu atraksi atau } \\
\text { hiburan. } \\
\text { Giva Pavule } \\
(2006: 27) .\end{array}$ & $\begin{array}{l}\text { budaya seperti } \\
\text { bangunan } \\
\text { bersejarah di } \\
\text { Kota Pekanbaru. } \\
\text { Keragaman } \\
\text { wisata belanja di } \\
\text { Kota Pekanbaru. }\end{array}$ & $\begin{array}{l}\text { Pekanbaru. } \\
\text { - Tingkat } \\
\text { keragaman } \\
\text { budaya } \\
\text { seperti } \\
\text { bangunan } \\
\text { bersejarah di } \\
\text { Kota } \\
\text { Pekanbaru. } \\
\text { Tingkat } \\
\text { keragaman } \\
\text { wisata } \\
\text { belanja di } \\
\text { kota } \\
\text { Pekanbaru }\end{array}$ & & A.II. 17 \\
\hline $\begin{array}{l}\text { Keputusan } \\
\text { Berkunjung } \\
\text { (Y) }\end{array}$ & \multicolumn{5}{|c|}{$\begin{array}{l}\text { Arianto } 2005 \text {, Faktor-faktor utama dan faktor lain yang mempengaruhi } \\
\text { permintaan pariwisata yaitu lokasi, fasilitas, citra/image, Harga/tariff dan } \\
\text { pelayanan. }\end{array}$} \\
\hline Lokasi & $\begin{array}{l}\text { Dari segi lokasi } \\
\text { ini, pembeli akan } \\
\text { memilih lokasi } \\
\text { yang benar-benar } \\
\text { strategis dan } \\
\text { tidak } \\
\text { membutuhkan } \\
\text { terlalu banyak } \\
\text { waktu, tenaga, } \\
\text { dan biaya } \\
\text { seperti: mudah } \\
\text { dijangkau, }\end{array}$ & 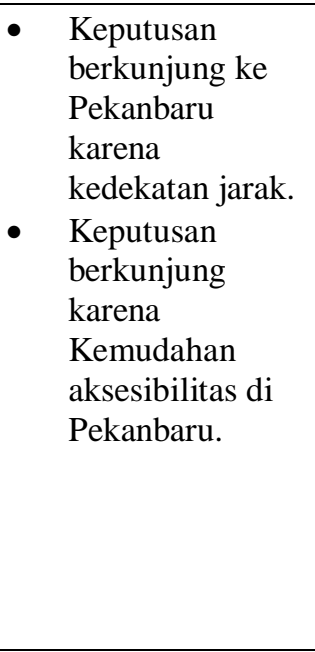 & $\begin{array}{l}\text { Tingkat } \\
\text { keputusan } \\
\text { berkunjung } \\
\text { ke } \\
\text { Pekanbaru } \\
\text { karena } \\
\text { kedekatan } \\
\text { jarak. } \\
\text { Tingkat } \\
\text { keputusan } \\
\text { berkunjung } \\
\text { karena } \\
\text { Kemudahan } \\
\text { aksesibilitas } \\
\text { di } \\
\text { Pekanbaru. }\end{array}$ & Ordinal & B.II.1 \\
\hline Fasilitas & $\begin{array}{l}\text { Fasilitas } \\
\text { fungsinya adalah } \\
\text { memenuhi } \\
\text { kebutuhan } \\
\text { wisatawan } \\
\text { selama tinggal } \\
\text { untuk sementara } \\
\text { waktu di DTW } \\
\text { yang dikunjungi. } \\
\text { Termasuk dalam } \\
\text { kelompok ini } \\
\text { menurut Victor } \\
\text { T.C. Milddelton } \\
\text { dalam Yoeti } \\
\text { (2005: 4) adalah } \\
\text { Accomondation } \\
\text { Units, Restoran, } \\
\text { Bars dan café, } \\
\text { Transportation }\end{array}$ & 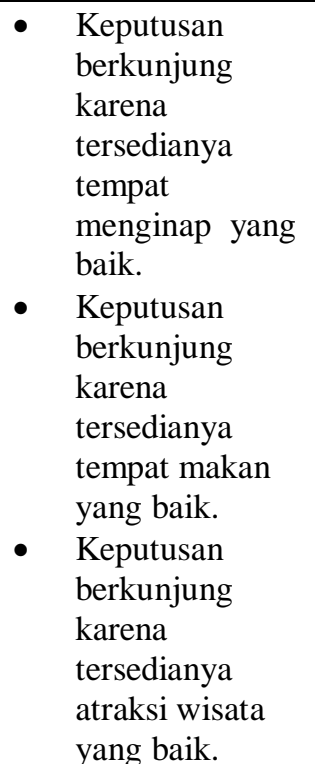 & $\begin{array}{ll}\text { - } & \text { Tingkat } \\
\text { keputusan } \\
\text { berkunjung } \\
\text { karena } \\
\text { tersedianya } \\
\text { tempat } \\
\text { menginap } \\
\text { yang baik. } \\
\text { Tingkat } \\
\text { keputusan } \\
\text { berkunjung } \\
\text { karena } \\
\text { tersedianya } \\
\text { tempat } \\
\text { makan yang } \\
\text { baik } \\
\text { Tingkat } \\
\text { keputusan } \\
\text { berkunjung }\end{array}$ & Ordinal & B.II.4 \\
\hline
\end{tabular}




\begin{tabular}{|c|c|c|c|c|c|}
\hline & $\begin{array}{l}\text { at the } \\
\text { destination, } \\
\text { sport and } \\
\text { aktivitis, others } \\
\text { facilities, Retail } \\
\text { outlets, others } \\
\text { service. Ariyanto } \\
(2005)\end{array}$ & $\begin{array}{l}\text { Keputusan } \\
\text { berkunjung } \\
\text { karena Sarana } \\
\text { transportasi } \\
\text { yang baik di } \\
\text { Kota } \\
\text { Pekanbaru. }\end{array}$ & $\begin{array}{l}\text { karena } \\
\text { tersedianya } \\
\text { atraksi } \\
\text { wisata yang } \\
\text { baik. } \\
\text { Tingkat } \\
\text { keputusan } \\
\text { berkunjung } \\
\text { karena } \\
\text { transportasi } \\
\text { yang baik } \\
\text { di Kota } \\
\text { Pekanbaru. }\end{array}$ & & B.II.6 \\
\hline $\begin{array}{l}\text { Citra/ } \\
\text { image }\end{array}$ & $\begin{array}{l}\text { Setiap daerah } \\
\text { tujuan wisata } \\
\text { mepunyai citra } \\
\text { (image) tertentu } \\
\text { yaitu mental map } \\
\text { seseorang } \\
\text { terhadap suatu } \\
\text { destnasi yang } \\
\text { mengandung } \\
\text { kenyakinan, } \\
\text { kesan dan } \\
\text { persepsi. Citra } \\
\text { yang terbentuk } \\
\text { dipasar } \\
\text { merupakan } \\
\text { kombinasi antara } \\
\text { berbagai faktor } \\
\text { yang ada pada } \\
\text { destinasi yang } \\
\text { bersangkutan } \\
\text { (seperti cuaca, } \\
\text { pemandangan } \\
\text { alam, keamanan, } \\
\text { kesehatan dan } \\
\text { sanitasi, keramah } \\
\text { tamahan, dan } \\
\text { lain-lain) } \\
\text { Ariyanto (2005) }\end{array}$ & $\begin{array}{ll}\text { Keputusan } \\
\text { berkunjung } \\
\text { karena citra } \\
\text { pemandangan } \\
\text { alam di Kota } \\
\text { Pekanbaru. } \\
\text { Keputusan } \\
\text { berkunjung } \\
\text { karena citra } \\
\text { keunikan } \\
\text { budaya seperti } \\
\text { bangunan } \\
\text { bersejarah. } \\
\text { Keputusan } \\
\text { berkunjung } \\
\text { karena keramah- } \\
\text { tamahan } \\
\text { masyarakat kota } \\
\text { Pekanbaru. }\end{array}$ & $\begin{array}{ll}\text { - } & \text { Tingkat } \\
\text { Keputusan } \\
\text { berkunjung } \\
\text { karena citra } \\
\text { pemandang } \\
\text { an alam di } \\
\text { Kota } \\
\text { Pekanbaru. } \\
\text { Tingkat } \\
\text { Keputusan } \\
\text { berkunjung } \\
\text { karena citra } \\
\text { citra } \\
\text { keunikan } \\
\text { budaya } \\
\text { seperti } \\
\text { bangunan } \\
\text { bersejarah. } \\
\text { Tingkat } \\
\text { Keputusan } \\
\text { berkunjung } \\
\text { karena } \\
\text { keramah- } \\
\text { tamahan } \\
\text { masyarakat } \\
\text { kota } \\
\text { Pekanbaru. }\end{array}$ & Ordinal & B.II.8 \\
\hline $\begin{array}{c}\text { Harga/ } \\
\text { tarif }\end{array}$ & $\begin{array}{l}\text { harga yang } \\
\text { tinggi pada suatu } \\
\text { daerah tujuan } \\
\text { wisata maka } \\
\text { akan } \\
\text { memberikan } \\
\text { imbas/timbal } \\
\text { balik pada } \\
\text { wisatawan yang } \\
\text { akan } \\
\text { bepergian/calon } \\
\text { wisata, sehingga }\end{array}$ & $\begin{array}{ll}\text { - } & \text { Keputusan } \\
\text { berkunjung } \\
\text { karena harga } \\
\text { paket wisata } \\
\text { yang ditawarkan } \\
\text { murah. } \\
\text { Keputusan } \\
\text { berkunjung } \\
\text { karena makanan } \\
\text { di Kota } \\
\text { Pekanbaru } \\
\text { murah. } \\
\end{array}$ & $\begin{array}{ll}\text { - } & \text { Tingkat } \\
\text { keputusan } \\
\text { berkunjung } \\
\text { karena } \\
\text { harga paket } \\
\text { wisata yang } \\
\text { ditawarkan } \\
\text { murah. } \\
\text { Tingkat } \\
\text { Keputusan } \\
\text { berkunjung } \\
\text { karena } \\
\end{array}$ & Ordinal & B.II.10 \\
\hline
\end{tabular}




\begin{tabular}{|c|c|c|c|c|c|}
\hline & $\begin{array}{l}\text { permintaan } \\
\text { wisatapun akan } \\
\text { berkurang } \\
\text { begitupula } \\
\text { sebaliknya. } \\
\text { Ariyanto (2005) }\end{array}$ & $\begin{array}{l}\text { - Keputusan } \\
\text { berkunjung } \\
\text { karena } \\
\text { cinderamata di } \\
\text { Kota Pekanbaru } \\
\text { murah. }\end{array}$ & $\begin{array}{l}\text { makanan di } \\
\text { Kota } \\
\text { Pekanbaru } \\
\text { murah. } \\
\text { - Tingkat } \\
\text { Keputusan } \\
\text { berkunjung } \\
\text { karena } \\
\text { cinderamata } \\
\text { di Kota } \\
\text { Pekanbaru } \\
\text { murah. }\end{array}$ & & B.II.12 \\
\hline Pelayanan & $\begin{array}{l}\text { Pelayanan yang } \\
\text { kurang baik akan } \\
\text { menimbulkan } \\
\text { rasa tidak puas } \\
\text { yang dirasakan } \\
\text { oleh konsumen } \\
\text { yang selanjutnya } \\
\text { akan } \\
\text { mempengaruhi } \\
\text { tingkat penjualan } \\
\text { pada waktu } \\
\text { selanjutnya. } \\
\text { Ariyanto (2005) }\end{array}$ & $\begin{array}{l}\text { Keputusan } \\
\text { berkunjung } \\
\text { karena } \\
\text { pelayanan di } \\
\text { bandara } \\
\text { Pekanbaru } \\
\text { memuaskan. } \\
\text { Keputusan } \\
\text { berkunjung } \\
\text { karena } \\
\text { pelayanan di } \\
\text { daya tarik } \\
\text { wisata } \\
\text { memuaskan. } \\
\text { Keputusan } \\
\text { berkunjung } \\
\text { karena } \\
\text { pelayanan di } \\
\text { Penginapan } \\
\text { memuaskan } \\
\text { Keputusan } \\
\text { berkunjung } \\
\text { karena } \\
\text { pelayanan di } \\
\text { Rumah makan } \\
\text { memuaskan. }\end{array}$ & $\begin{array}{l}\text { Tingkat } \\
\text { Keputusan } \\
\text { berkunjung } \\
\text { karena } \\
\text { Pelayanan } \\
\text { di bandara } \\
\text { pekanbaru } \\
\text { memuaskan. } \\
\text { Tingkat } \\
\text { Keputusan } \\
\text { berkunjung } \\
\text { karena } \\
\text { pelayanan } \\
\text { di daya tarik } \\
\text { wisata } \\
\text { memuaskan. } \\
\text { Tingkat } \\
\text { keputusan } \\
\text { berkunjung } \\
\text { karena } \\
\text { pelayanan } \\
\text { di } \\
\text { penginapan } \\
\text { memuaskan. } \\
\text { Tingkat } \\
\text { Keputusan } \\
\text { berkunjung } \\
\text { karena } \\
\text { pelayanan } \\
\text { di rumah } \\
\text { makan } \\
\text { memuaskan. }\end{array}$ & Ordinal & B.II.13 \\
\hline \multicolumn{6}{|c|}{$\begin{array}{ll}\text { Sumber: Diolah Penulis 2011. } & \text { waktu, maka peneliti dapat menggunakan } \\
\text { 3.2.3 Metode Penarikan Sampel } & \text { sampel yang diambil dari populasi tersebut. } \\
\text { Menurut Sugiyono (2008:116), sampel } & \text { Penarikan sampel ditujukan untuk } \\
\text { memudahkan peneliti dalam melakukan } \\
\text { adalah bagian dari jumlah dan karakteristik } & \text { penelitian. Sampel merupakan perwakilan dari } \\
\text { yang dimiliki oleh populasi tersebut. Bila } & \text { populasi penelitian, dengan adanya sampel, } \\
\text { populasi besar, dan penelitian tidak mungkin } & \text { maka waktu, tenaga dan biaya yang } \\
\text { mempelajari semua yang ada pada populasi, } & \text { dikeluarkan oleh peneliti menjadi lebih efisien. }\end{array}$} \\
\hline
\end{tabular}


Data yang telah dimiliki berupa populasi sebesar 10435 orang. Ukuran sampel tersebut diperoleh berdasarkan hasil perhitungan dengan menggunakan rumus Slovin (Husein Umar, 2009:78) Maka akan didapat jumlah populasi sebesar 10435. Berdasarkan penghitungan, maka ukuran sampel minimal dalam penelitian ini adalah sebanyak 210 orang yang merupakan wisatawan asal Malaysia yang berkunjung ke Kota Pekanbaru.

\subsubsection{Prosedur Pengumpulan Data}

Pengumpulan data yang dilakukan penulis menggunakan teknik sebagai berikut.

1. Wawancara,

2. Kuesioner,

3. Observasi,

4. Studi kepustakaan untuk mengumpulkan data sekunder.

\subsubsection{Analisis Jalur (Path Analysis)}

Analisis ini digunakan untuk menentukan berapa besar pengaruh suatu variabel terhadap variabel lainnya, baik pengaruh langsung maupun tidak langsung. Besarnya pengaruh dari suatu variabel penyebab (independen) terhadap variabel akibat (dependen) disebut koefisien jalur $\left(\mathrm{P}_{\mathrm{yx}}\right)$. Hipotesis tersebut digambarkan dalam sebuah paradigma seperti terlihat pada Gambar 3.1 berikut:

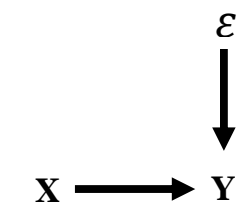

GAMBAR 3.1

STRUKTUR KAUSAL ANTARA X DAN Y Keterangan :

$\varepsilon \quad=$ Epsilon (Variabel lain)

$\longrightarrow=$ Hubungan Kausalitas

Struktur hubungan diatas menunjukkan bahwa faktor-faktor psikologis berpengaruh signifikan terhadap keputusan berkunjung baik secara parsial maupun simultan. Selain itu terdapat faktor-faktor lain yang mempengaruhi hubungan antara variabel Faktor-faktor Pendorong (X) dengan Keputusan Berkunjung (Y), yaitu $\varepsilon$ (variabel lain), namun pada penelitian ini variabel tersebut tidak diperhatikan.
Struktur hubungan antara $\mathrm{X}$ dan $\mathrm{Y}$ diuji melalui analisis jalur dengan hipotesis berbunyi terdapat pengaruh signifikan antara faktor-faktor penarik yang terdiri dari aksesibilitas, ketersedian jasa atau service, budaya, stabilitas politik dan keamanan, ketersediaannya atraksi, terhadap keputusan berkunjung (Y) baik secara parsial maupun simultan. Struktur hipotesis yang diterjemahkan ke dalam diagram hipotesis yang menyatakan pengaruh sub variabel bebas terhadap variabel terikat digambarkan pada Gambar 3.2 berikut:

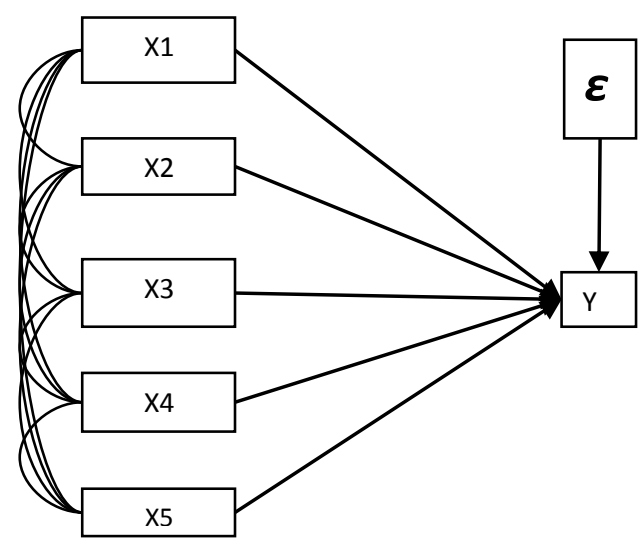

\section{GAMBAR 3.2 \\ STRUKTUR HIPOTESIS}

Pengaruh variabel lain (E) dihitung dengan rumus sebagai berikut:

$\rho Y \varepsilon=\sqrt{1-R^{2}} \mathrm{Y}(\mathrm{X} 1, \mathrm{X} 2, \mathrm{X} 3, \mathrm{X} 4, \mathrm{X} 5)$

Keputusan penerimaan atau penolakan Ho Rumusan hipotesis operasional:

Ho $: \rho \mathrm{YX}_{1}=\rho \mathrm{YX}_{2}=\rho \mathrm{YX}_{3}=\rho \mathrm{YX}_{4}=$ $\rho \mathrm{YX}_{5}=0$

Hi : Sekurang-kurangnya ada sebuah $\rho \mathrm{YX}_{1} \mathrm{i} \neq 0,1=1,2,3,4$, dan 5 .

Statistik uji yang digunakan adalah $\mathrm{F}=$ $\frac{(n-k-1) \sum_{i=1}^{n} \rho \text { YXi } \rho \text { YXi }}{(n-k-1) \sum_{i=1}^{n} \rho \text { YXi } \rho \text { YXi }}$

Hasil $\mathrm{F}$ hitung dibandingkan dengan tabel distribusi F Snedecor, apabila $\mathrm{F}$ hitung $\geq \mathrm{F}$ tabel, maka Ho ditolak dengan demikian dapat diteruskan pada pengujian secara individual, statistic yang digunakan adalah:

$$
t=\frac{\rho Y X i-\rho Y X i}{\sqrt{\frac{\left(1-R^{2} Y(X 1, X 2, X 3)\right)\left(C_{i i}+C_{i j}+C_{j j}\right)}{(n-k-1)}}}
$$


Pengujian hipotesis dibantu dengan menggunakan software program SPSS Versi 12 yaitu menguji pengaruh variabel Faktorfaktor penarik terhadap yaitu Keputusan berkunjung (Y).

Kriteria pengambilan keputusan untuk hipotesis yang diajukan adalah:

Jika $t_{\text {hitung }} \leq t_{\text {tabel }}$, maka $\mathrm{H}_{0}$ diterima dan $\mathrm{H}_{1}$ ditolak

Jika $t_{\text {hitung }}>t_{\text {tabel }}$, maka $\mathrm{H}_{0}$ ditolak dan $\mathrm{H}_{1}$ diterima

Pada taraf kesalahan 0,07 dengan derajat kebebasan dk (n-2)

\section{HASIL PENELITIAN DAN} PEMBaHASAN

4.1 Rekapitulasi

Wisatawan Nusantara Terhadap

Faktor-Faktor Pendorong

Berdasarkan hasil pengumpulan data, diperoleh rekapitulasi tanggapan wisatawan mengenai faktor-faktor penarik Kepariwisataan wisatawan asal Malysia ke kota pekanbaru. Hasil rekapitulasi tanggapantanggapan wisatawan asal Malaysia dapat diperlihatkan pada Tabel 4.1 di bawah ini:

TABEL 4.1

REKAPITULASI HASIL TANGGAPAN TERHADAP FAKTOR-FAKTOR PENARIK KEPARIWISATAAN WISATAWAN ASAL MALAYSIA

\begin{tabular}{|c|c|c|c|c|}
\hline $\mathrm{N}$ & Sub Variabel & $\begin{array}{l}\text { Total } \\
\text { Skor }\end{array}$ & $\begin{array}{l}\text { Skor } \\
\text { Rata- } \\
\text { rata }\end{array}$ & $\%$ \\
\hline 1 & $\begin{array}{c}\text { AKSESIBILIT } \\
\text { AS }\end{array}$ & 4249 & $\begin{array}{l}708.1 \\
6 \\
\end{array}$ & $\begin{array}{c}22.3 \\
0\end{array}$ \\
\hline 2 & $\begin{array}{c}\text { KETERSEDIA } \\
\text { N JASA ATAU } \\
\text { SERVICE }\end{array}$ & 2732 & 683 & $\begin{array}{c}21.5 \\
1\end{array}$ \\
\hline 3 & BUDAYA & 1715 & $\begin{array}{l}571.1 \\
6\end{array}$ & $\begin{array}{c}17.9 \\
9\end{array}$ \\
\hline 4 & $\begin{array}{c}\text { STABILITAS } \\
\text { POLITIK DAN } \\
\text { KEAMANAN }\end{array}$ & 1078 & 539 & $\begin{array}{c}16.9 \\
7\end{array}$ \\
\hline 5 & $\begin{array}{l}\text { KETERSEDIA } \\
\text { AN ATRAKSI }\end{array}$ & 2023 & $\begin{array}{l}674.3 \\
3 \\
\end{array}$ & $\begin{array}{c}21.2 \\
3 \\
\end{array}$ \\
\hline & Total & 11797 & $\begin{array}{c}3175 . \\
65\end{array}$ & 100 \\
\hline
\end{tabular}

Sumber : Hasil pengolahan data 2011

Berdasarkan Tabel 4.1, dapat dilihat bahwa sub variabel dari faktor-faktor-faktor penarik kepariwisataan wisatawan asal Malaysia yang mendapat penilaian yang paling tinggi yaitu Aksesibilitas (22.30\%) hal ini di karenakan kemudahan aksesibitas ke Kota Pekanbaru yang letaknya strategis dengan Malaysia, dan tersedianya bus transmetro yang mengangkut wisatawan dari bandara untuk transit di setiap ojek wisata, tempat penginapan dan pusat perbelanjaan di Kota Pekanbaru. Sedangkan sub variabel yang mendapatkan penilaian yang terendah yaitu stabilitas politik dan keamanan sebesar (16.67\%). Hal ini di karenakan kondisi stabilitas politik yang belum stabil dampak dari pemilu pilkada yang gagal sehingga banyak demontrasi yang menyebabkan kemacetan dan sering terjadi Berdasarkan hal tersebut maka Gambar 4.1 Menjelaskan tanggapan persepsi wisatawan asal Malaysia mengenai faktor-faktor penarik kepariwisataan di Kota Pekanbaru.

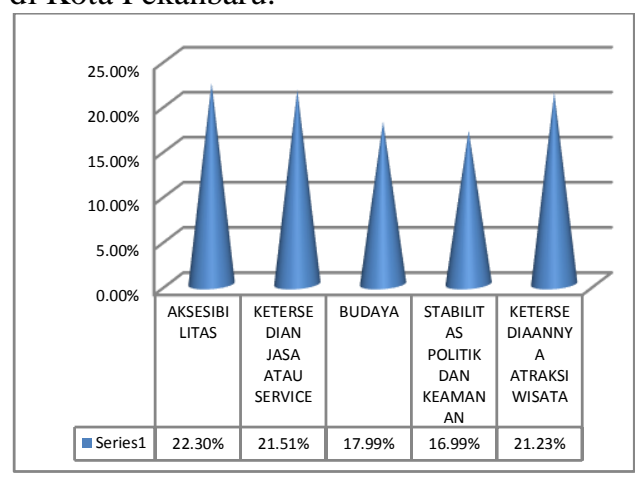

\section{GAMBAR 4.1}

TANGGAPAN FAKTOR-FAKTOR PENARIK KEPARIWISATAAN WISATAWAN ASAL MALAYSIA

Sumber : Hasil Pengolahan Data Primer, 2011.

Berdasarkan pengolahan yang disajikan pada Gambar 4.1, dapat dilihat bahwa skor total untuk faktor-faktor penarik kepariwisataan di Kota Pekanbaru adalah jumlah 11797 skor tersebut di masukan ke dalam garis kontium, yang pengukurannya di tentukan dengan cara:

1. Indek Maksimum $=5 \times 18 \times 210=18900$

2. Nilai Indeks Minimum $=1 \times 18 \times 210=3780$

3. Jarak interval (Nilai indeks maksimum: banyaknya kelas interval $)=(18900: 5)=$ 3780

4. Presentasi skor= (total skor): nilai maksimum) x 100\%

$=(11797: 18900) \times 100 \%$

$=62.38 \%$. 
Secara ideal, skor yang diharapkan untuk jawaban konsumen terhadap pertanyaan tentang faktor-faktor penarik kepariwisataan di Kota Pekanbaru adalah 18900. Dari perhitungan dalam Tabel 4.1 Menunjukan nilai yang diperoleh 11797 atau $62.38 \%$ dari skor ideal yaitu 18900. Hasil tersebut menunjukan bahwa persepsi wisatawan Asal Malasia terhadap faktor-faktor penarik kepariwisataan di Kota Pekanbaru di nilai wisatawan dapat di katakan cukup tinggi.

\subsection{Rekapitulasi Hasil Tanggapan Wisatawan Nusantara Terhadap Keputusan Berkunjung}

Rekapitulasi Hasil Tanggapan terhadap keputusan berkunjung dilihat pada Tabel yang disajikan berikut ini:

TABEL 4.2

\section{REKAPITULASI HASIL TANGGAPAN TERHADAP KEPUTUSAN \\ BERKUNJUNG WISATAWAN ASAL MALAYSIA}

\begin{tabular}{|c|l|c|c|c|}
\hline No & $\begin{array}{c}\text { Sub } \\
\text { Variabel }\end{array}$ & $\begin{array}{c}\text { Total } \\
\text { Skor }\end{array}$ & $\begin{array}{c}\text { Skor } \\
\text { Rata- } \\
\text { rata }\end{array}$ & $\%$ \\
\hline 1 & Lokasi & 1871 & 935.5 & 24.87 \\
\hline 2 & Fasilitas & 2654 & 663.5 & 17.64 \\
\hline 3 & Citra & 2238 & 746 & 19.83 \\
\hline 4 & Harga & 1944 & 648 & 17.22 \\
\hline 5 & Pelayanan & 3076 & 769 & 20.44 \\
\hline \multicolumn{2}{|c|}{ Total } & 11783 & 3762 & 100 \\
\hline
\end{tabular}

Sumber: Hasil pengolahan data 2011

Berdasarkan Tabel 4.2, dapat dilihat bahwa sub variabel dari rekapitulasi hasil tanggapan terhadap keputusan berkunjung wisawan asal Malaysia yang mendapat penilaian yang paling tinggi yaitu pada lokasi sebesar (24.86\%). Hal ini dikarenakan kedekatan lokasi antara kota Pekanbaru dan Malaysia sehingga wisatawan tertarik untuk berkunjung ke Kota Pekanbaru. Sedangkan penilaian yang paling rendah pada harga hal ini karena harga. Hal ini karena harga distribusi barang yang di jual di Pekanbaru kebanyakan berasal dari luar daerah. Harga paket wisata yang cukup mahal karena kota Pekanbaru mempromosikan objek wisata secara tunggal. Kebanyakan wisatawan menginginkan paket wisata yang menggabungkan dua propinsi yaitu berawal kota Pekanbaru dan berakhir di Kota Padang. Sedangkan paket travel yang tersedia di Kota pekanbaru kebanyakan hanya di lingkungan Kota Pekanbaru sehingga menimbulkan kurang ketertarikannya bagi wisatawan. Dimana harga yang tinggi pada suatu daerah tujuan wisata maka akan memberikan imbas/timbal balik pada wisatawan yang akan bepergian/calon wisata, sehingga permintaan wisatapun akan berkurang begitupula sebaliknya.

Berdasarkan hal tersebut maka Gambar 4.2 Menjelaskan tanggapan wisatawan asal Malaysia mengenai keputusan berkunjung ke Kota Pekanbaru.

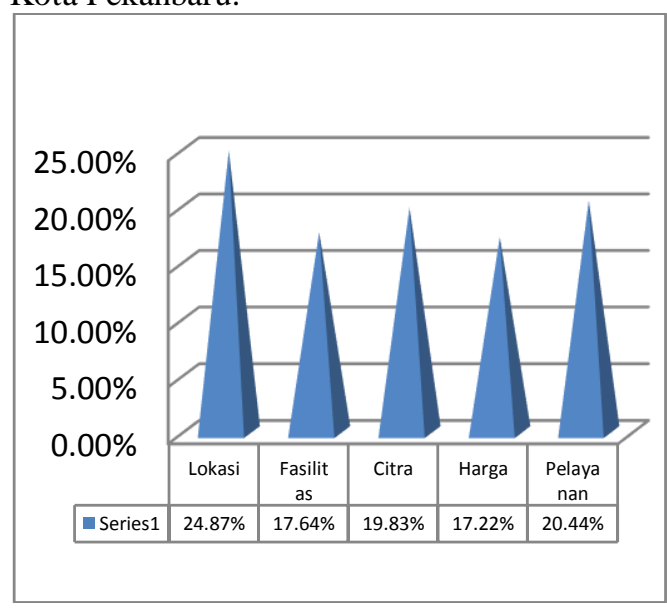

\section{GAMBAR 4.2}

TANGGAPAN WISATAWAN ASAL MALAYSIA MENGENAI KEPUTUSAN BERKUNJUNG KE KOTA PEKANBARU

Berdasarkan pengolahan yang disajikan pada Gambar 4.2, dapat dilihat bahwa skor total untuk faktor-faktor penarik kepariwisataan di Kota Pekanbaru adalah jumlah 11784 skor tersebut di masukan ke dalam garis kontium, yang pengukurannya di tentukan dengan cara:

1. Indek Maksimum $=5 \times 16 \times 210=16800$

2. Nilai Indeks Minimum $=1 \times 16 \times 210=3360$

3. Jarak interval (Nilai indeks maksimum: banyaknya kelas interval)

$=(16800: 5)=3360$

4. Presentasi skor= (total skor): nilai maksimum) x 100\%

$=(11784: 16800) \times 100 \%$

$=70.14 \%$.

Secara ideal, skor yang diharapkan untuk jawaban konsumen terhadap pertanyaan tentang keputusan berkunjung adalah 16800 . Berdasarkan perhitungan menunjukan nilai yang diperoleh 11784 atau $70.14 \%$ dari skor 
ideal yaitu 16800. Hasil tersebut menunjukan bahwa Keputusan berkunjung ke Kota Pekanbaru di nilai wisatawan Asal Malaysia dapat di katakan cukup tinggi.

\subsection{Pengujian Hipotesis.}

Pengujian hipotesis dilakukan untuk menguji dan mengetahui pengaruh faktorfaktor kepariwisataan wisatawaan asal Malaysia (X) yang terdiri dari Aksesibilitas (X1.1), ketersedian jasa dan service (X1.2), budaya (X3), stabilitas politik dan keamanan (X4), ketersediaanya atraksi(X5), dilakukan dengan cara menganalisis hubungan pengaruh antara total skor item (X1.1), (X1.2), (X1.3), (X1.4), (X1.5) berpengaruh terhadap Keputusan berkunjung ke Kota Pekanbaru (Y) dengan menggunakan uji statistic analisis jalur (path analisis).

Analisis jalur digunakan untuk mengetahui pengaruh langsung dan tidak langsung antara pengaruh persepsi wisatawan asal Malaysia tentang fakor-faktor penarik kepariwisataan di Kota Pekanbaru terhadap keputusan berkunjung. Serta untuk menghitung besarnya koefisien jalur masingmasing variabel. Selanjutnya berdasarkan perhitungan statistik yang didasarkan pada angka-angka pada masing-masing variabel terlebih dahulu dilakukan transformasi, dimana dalam perhitungan transformasi dilkakan dengan program software komputer SPSS (Statistical Product for Service Solution) Versi 12,0.

Secara lengkap hasil pengolahan data Faktor-faktor penarik kepariwisataan wisatawan asal Malaysia beserta 5 sub varibel terhadap keputusan berkunjung ke Kota Pekanbaru, disajikan secara rinci sebagai berikut. 
TABEL 4.3

\begin{abstract}
MATRIKS KORELASI ANTAR SUB VARIABEL FAKTOR-FAKTOR PENARIK KEPARIWISATAAN WISATAWAN ASAL MALAYSIA TERHADAP KEPUTUSAN BERKUNJUNG KE KOTA PEKANBARU
\end{abstract}

\begin{tabular}{|c|c|c|c|c|c|c|}
\hline & Y & $\begin{array}{c}\text { Aksesi } \\
\text { bilitas }\end{array}$ & $\begin{array}{c}\text { Keterse } \\
\text { diaan } \\
\text { Jasa } \\
\text { atau } \\
\text { service }\end{array}$ & Budaya & $\begin{array}{c}\text { Stabilitas } \\
\text { politik dan } \\
\text { keamanan }\end{array}$ & $\begin{array}{c}\text { Ketersedi } \\
\text { aanya } \\
\text { atraksi } \\
\text { wisata }\end{array}$ \\
\hline Y & 1 & 0.651 & 0.620 & 0.393 & 0.357 & 0.434 \\
\hline Aksesibilitas & 0.651 & 1 & 0.520 & 0.208 & 0.187 & 0.262 \\
\hline Ketersediaan Jasa atau service & 0.620 & 0.520 & 1 & 0.227 & 0.192 & 0.255 \\
\hline Budaya & 0.393 & 0.208 & 0.227 & 1 & 0.189 & 0.205 \\
\hline Stabilitas politik dan keamanan & 0.357 & 0.187 & 0.192 & 0.189 & 1 & 0.193 \\
\hline Ketersediaanya atraksi wisata & 0.434 & 0.262 & 0.255 & 0.205 & 0.193 & 1 \\
\hline
\end{tabular}

Sumber : Hasil pengolahan data, 2011.

Berdasarkan hasil matrik korelasi sub variabel antara tentang faktor-faktor kepariwisataan wisatawan asal Malaysia dengan keputusan berkunjung ke Kota Pekanbaru di peroleh korelasi berurutan yaitu $0.651,0.620,0.393,0.357$, dan 0.434 .

Tabel 4.3, menunjukan hubungan setiap sub variabel faktor-faktor kepariwisataan wisatawan asal Malaysia (X) dari aksesibilitas (X1) hingga ketersediaannya atraksi (X5) dengan Y (Keputusan berkunjung ke Kota Pekanbaru). Berdasarkan Tabel 4.3 di ketahui bahwa nilai yang terbesar adalah hubungan antara faktor-faktor kepariwisataan wisatawan asal Malaysia dengan keputusan berkunjung ke Kota Pekanbaru sebesar 0,651 koefisien tersebut menunjukan bahwa antara aksesibilitas dengan keputusan berkunjung memiliki hubungan yang signifikan.

Berdasarkan hasil korelasi, selanjutnya untuk menguji koefisien jalur berdasarkan teori bahwa terdapat pengaruh analisis faktorfaktor penarik yang terdiri dari lini Aksesibilitas (X1.1), ketersedian jasa dan service (X1.2), budaya (X3), stabilitas politik dan keamanan (X4), ketersediaanya atraksi(X5) terhadap keputusan berkunjung (Y) akan dilakukan uji $\mathrm{F}$ untuk mengetahui hasil hipotesis. Secara lengkap hasil pengolahan data uji F melalui program SPSS (Statistical Product for Service Solution) 12.0. disajikan secara rinci sebagai berikut:

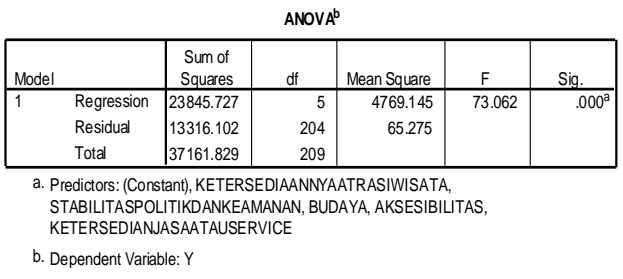

Berdasarkan hasil ouput SPSS diatas dapat dilihat bahwa nilai $\mathrm{F}$ sebesar 73.062 dengan probabilitas sebesar 0,000 lebih kecil dari 0,07. Sehingga dapat disimpulkan Ho ditolak, artinya proses perhitungan atau pengujian secara individual dapat dilanjutkan. Untuk lebih jelasnya, pengujian koefisien jalur setiap variabel diperlihatkan dalam Tabel berikut ini.

\begin{tabular}{|c|c|c|c|c|c|c|}
\hline \multirow[b]{3}{*}{ Model } & \multicolumn{6}{|c|}{ Coefficients $^{2}$} \\
\hline & & \multicolumn{2}{|c|}{$\begin{array}{l}\text { Unstandardized } \\
\text { Coefficients }\end{array}$} & \multirow{2}{*}{$\begin{array}{c}\text { Standardized } \\
\text { Coefficients }\end{array}$} & \multirow[b]{2}{*}{$t$} & \multirow[b]{2}{*}{ Sig. } \\
\hline & & B & Std. Error & & & \\
\hline 1 & (Constant) & 11.413 & 2.469 & & 4.622 & .000 \\
\hline & AKSESIBILITAS & .777 & .104 & .374 & 7.454 & .000 \\
\hline & $\begin{array}{l}\text { KETERSEDIANJA } \\
\text { SAATAUSERVICE }\end{array}$ & .866 & .143 & .304 & 6.053 & .000 \\
\hline & BUDAYA & .583 & .145 & .177 & 4.024 & .000 \\
\hline & $\begin{array}{l}\text { STABILITASPOLITI } \\
\text { KDANKEAMANAN }\end{array}$ & .969 & .268 & .158 & 3.613 & .000 \\
\hline & $\begin{array}{l}\text { KETERSEDIAANN } \\
\text { YAATRASIWISATA }\end{array}$ & .794 & . 185 & .192 & 4.289 & .000 \\
\hline
\end{tabular}

Sumber: Hasil Pengolahan Data Primer, 2011.

Pengujian secara individu seperti terlihat pada Tabel 4.4 di atas menjelaskan bahwa variabel $\mathrm{X}_{1.1}$ memiliki nilai koefisien jalur sebesar 0,374 dengan tingkat signifikansi 
0,000 selanjutnya $X_{1.2}$ memiliki nilai koefisien jalur sebesar 0,304 dengan probabilita 0,000 kemudian $\mathrm{X}_{1.3}$ memiliki nilai koefisien jalur sebesar 0,177 dengan probabilitas yaitu sebesar 0.000. sedangkan $\mathrm{X}_{1.4}$ memiliki nilai koefisien jalur sebesar 0.158 dengan probabilitas 0.000 dan $\mathrm{X}_{1.5}$ memiliki nilai koefisien jalur sebesar 0.192 dengan probabilitas 0.000 . sub variabel $\mathrm{X}_{1.1}, \mathrm{X}_{1.2}, \mathrm{X}_{1.3}$, $\mathrm{X}_{1.4}$, dan $\mathrm{X}_{1.5}$ tersebut memiliki tingkat probabilitas di bawah 0,07 artinya variabel tersebut signifikan, sehingga dapat dinyatakan Ho ditolak, maka terdapat pengaruh yang signifikan. Secara lengkap strukural kausal antar variabel $\mathrm{X}_{1.1}, \mathrm{X}_{1.2}, \mathrm{X}_{1.3}, \mathrm{X}_{1.4}$ dan $\mathrm{X}_{1.5}$ terhadap $\mathrm{Y}$ dapat dilihat pada Gambar 4.3 berikut.
Gambar 4.3, menyajikan diagram jalur pengujian hipotesis, dimana pengujian hipotesis dalam penelitian ini menggunakan analisis jalur. Analisis jalur digunakan untuk mengetahui pengaruh langsung dan tidak langsung antara faktor-faktor kepariwisataan wisatawan asal Malaysia terhadap Keputusan berkunjung ke Kota Pekanbaru. Pengaruh langsung dan tidak langsung didapatkan dari perhitungan antara koefisien jalur dan korelasi, pada Tabel 4.5 berikut ini:

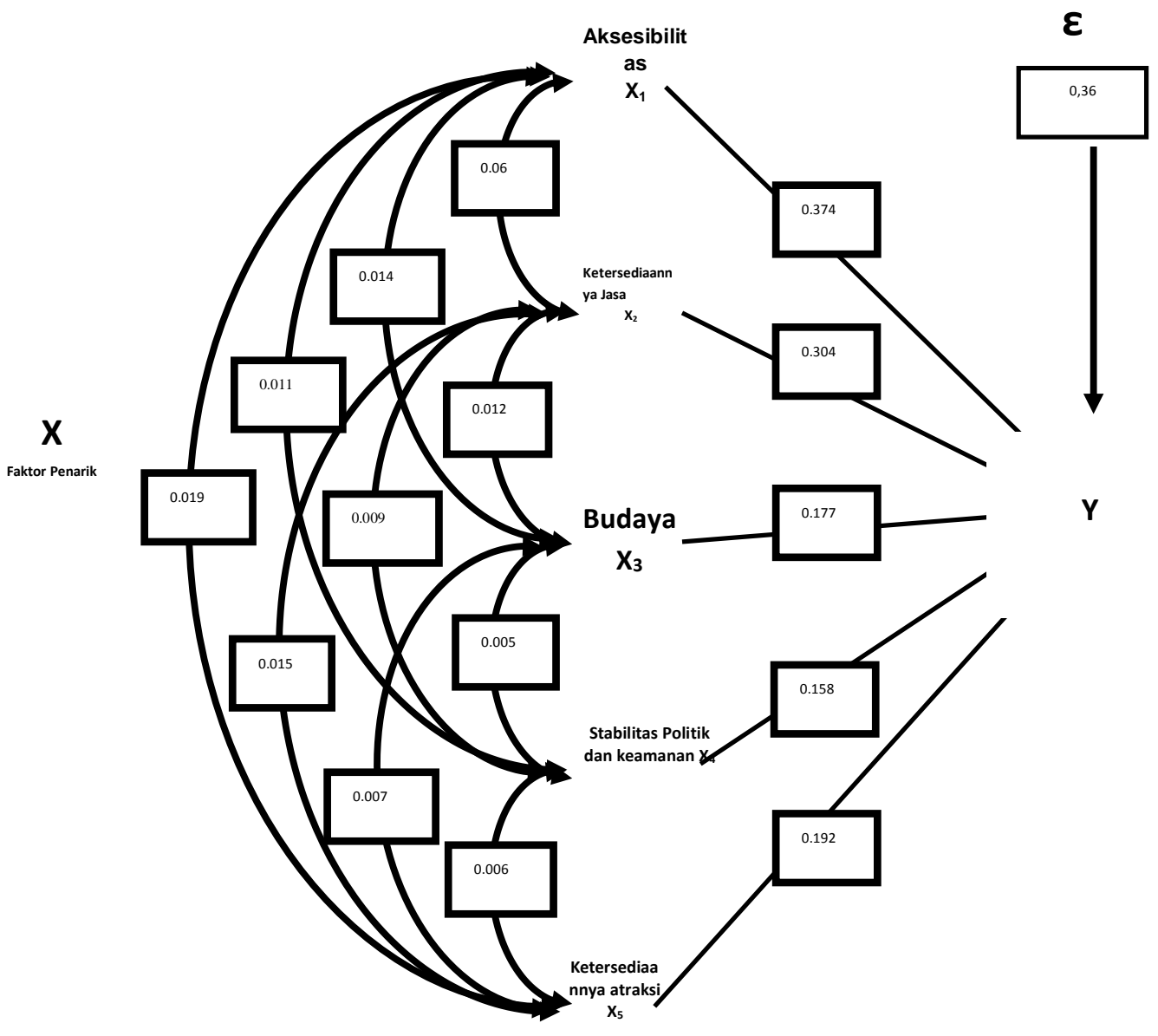

GAMBAR 4.3

DIAGRAM JALUR PENGUJIAN HIPOTESIS 
TABEL 4.5

HASIL PENGUJIAN KOEFISIEN JALUR PENGARUH LANGSUNG DAN TIDAK LANGSUNG DARI FAKTOR-FAKTOR PENARIK KEPARIWISATAN WISATAWAN ASAL MALAYSIA TERHADAP KEPUTUSAN

\begin{tabular}{|c|c|c|c|c|c|c|c|c|c|c|}
\hline \multirow[t]{2}{*}{$\mathrm{x}$} & \multirow{2}{*}{$\begin{array}{c}\text { Pengaruh } \\
\text { langsung } \\
\text { terhadap } \\
\text { Y }\end{array}$} & \multicolumn{5}{|c|}{ Pengaruh tidak langsung melalui } & \multirow{2}{*}{$\begin{array}{c}\text { Total } \\
\text { pengaruh }\end{array}$} & \multirow[b]{2}{*}{\begin{tabular}{l}
\multicolumn{1}{c}{$\mathrm{T}$} \\
hittmg \\
$\mathrm{T}$ \\
tabel \\
$=$ \\
1,821
\end{tabular}} & \multirow{2}{*}{$\begin{array}{c}\text { Sign } \\
\text { Alpha } \\
0,07\end{array}$} & \multirow[t]{2}{*}{ keputusan } \\
\hline & & $\mathrm{X} 1$ & $\mathrm{X} 2$ & $\mathrm{X} 3$ & $\mathrm{X} 4$ & $\mathrm{X} 5$ & & & & \\
\hline $\mathrm{X} 1$ & 0.14 & - & 0.06 & 0.014 & 0.011 & 0.019 & 0.244 & 7.454 & 0.000 & $\begin{array}{c}\text { Ho } \\
\text { ditolak }\end{array}$ \\
\hline $\mathrm{X} 2$ & 0.092 & 0.06 & - & 0.012 & 0.009 & 0.015 & 0.188 & 6.053 & 0.000 & $\begin{array}{c}\text { Ho } \\
\text { ditolak }\end{array}$ \\
\hline X3 & 0.031 & 0.014 & 0.012 & - & 0.005 & 0.007 & 0.069 & 4.024 & 0.000 & $\begin{array}{c}\text { Ho } \\
\text { ditolak }\end{array}$ \\
\hline $\mathrm{X} 4$ & 0.025 & 0.011 & 0.009 & 0.005 & - & 0.006 & 0.056 & 3.613 & 0.000 & $\begin{array}{c}\text { Ho } \\
\text { ditolak }\end{array}$ \\
\hline $\mathrm{X} 5$ & 0.039 & 0.019 & 0.015 & 0.007 & 0.006 & - & 0.086 & 4.289 & 0.000 & $\begin{array}{c}\text { Ho } \\
\text { ditolak }\end{array}$ \\
\hline $\mathrm{R}^{2}$ & & & & & & & 0.643 & & & \\
\hline
\end{tabular}

\section{BERKUNJUNG KE KOTA PEKANBARU}

Sumber: Hasil pengolahan data, 2011.

Hasil pengujian koefisien jalur menunjukan bahwa kelima dimensi pada persepsi wisatawan asal Malaysia tentang faktor-faktor penarik kepariwisataan di Kota Pekanbaru mempunyai nilai signifikan yang lebih kecil dari 0,07. Hal ini berarti hipotesis yang diajukan "tidak dapat perpengaruh positif antara faktor-faktor penarik kepariwisataan wisatawan asal Malaysia tehadap keputusan berkunjung ke Kota Pekanbaru ke Kota Pekanbaru"ditolak.

Pengaruh faktor-faktor penarik yang tertinggi pengaruhnya terhadap keputusan berkunjung adalah aksesibilitas yang berpengaruh langsung sebesar 14\% dan pengaruh tidak langsung sebesar $6 \%$.

Berdasarkan hasil perhitungan di atas maka pengaruh keseluruhan faktor-faktor penarik yang terdiri dari aksesibilitas, ketersediaanya jasa atau service, budaya, stabilitas politik dan keamanan, ketersediaanya atraksi terhadap keputusan berkunjung adalah sebesar 0.643. Untuk koefisien jalur variabel lainnya diluar dari aksesibilitas, ketersediaanya jasa atau service, budaya, stabilitas politik dan keamanan, ketersediaanya atraksi ditentukan melalui :

$$
\begin{aligned}
P_{Z \varepsilon} & =\sqrt{1-R_{Y(X 1, X 2)}^{2}} \\
& =\sqrt{1 \mathbf{1}-\mathbf{0 . 6 4 3}}
\end{aligned}
$$$$
=\sqrt{0,36}=0.6^{2}=0,36 \times 100 \%=36 \% \text {. }
$$

Hal tersebut menjelaskan bahwa aksesibilitas, ketersediaanya jasa atau service, budaya, stabilitas politik dan keamanan, ketersediaanya atraksi secara bersama-sama mempengaruhi keputusan berkunjung (Y) adalah sebesar $64.30 \%$ dan sisanya sebesar $(0.6)^{2}=0.36 \times 100 \%=36 \%$ dipengaruhi faktor lain yang tidak masuk ke dalam penelitian.

\section{KESIMPULAN}

Hasil penelitian mengenai faktor-faktor penarik kepariwisataan wisatwan asal Malaysia yang terdiri dari aksesibilitas, ketersediaan jasa atau service, budaya, stabilitas politik dan keamanan, serta ketersediaannya atraksi wisata terhadap keputusan berkunjung ke Kota Pekanbaru, sebagai berikut: 
1. Tanggapan faktor-faktor penarik kepariwisataan wisatawan asal Malaysia, secara umum memiliki penilaian yang cukup tinggi. Faktor yang mendapat penilaian yang paling tinggi yaitu pada faktor aksesibilitas sebesar 0,244 atau 24,4\%. Faktor berikutnya yaitu ketersedian jasa atau service yaitu sebesar 0,188 atau $18,8 \%$. Hal ini karena kesuksesan suatu produk pariwisata seringkali bergantung pada ketersedian atas fasilitas-fasilitas jasa, seperti akomodasi, makanan dan minuman, travel agency, Souvenir, iklan media masa dan lain-lain. Ketersediaannya fasilitas di daerah tujuan akan mempengaruhi seseorang wisatawan untuk berkunjung ke destinasi. Sedangkan kaktor ketersedian atraksi yaitu sebesar 0,086 atau 8,6\%. Hal ini karena ketersediaan atraksi wisata di kota pekanbaru yang terdiri dari atraksi alam, atraksi budaya, dan atraksi atraksi budaya di nilai wisatawan asal Malaysia cukup menarik. Namun yang mendapat penilian yang paling menarik yaitu wisata alam di kota Pekanbaru. Persepsi wisatawan asal Malaysia tentang faktor budaya di nilai rendah yaitu sebesar 0,069 atau $6,9 \%$. Hal ini dikarenakan mereka memiliki akar budaya yang sama sedangkan mereka berpergian ingin melihat budaya yang baru. Faktor berikutnya yang mendapat penilaian yang paling rendah yaitu stabilitas politik dan keamanan yaitu sebesar 0,056 atau 5,6\%. Hal ini karena kondisi stabilitas politik yang belum stabil.

2. Tanggapan wisatawan asal Malaysia terhadap keputusan berkunjung secara umum memiliki penilaian cukup tinggi terhadap program ini. Faktor yang mendapat penilaian yang paling tinggi yaitu pada lokasi sebesar $24.86 \%$. Hal ini dikarenakan kedekatan lokasi antara Kota Pekanbaru dengan Malaysia sehingga wisatawan tertarik untuk berkunjung. Sedangkan penilai yang paling rendah yaitu pada harga yaitu sebesar 17.22\% karena distribusi barang yang di jual di Pekanbaru kebanyakan berasal dari luar daerah. Harga paket wisata yang cukup mahal karena kota Pekanbaru mempromosikan objek wisata secara tunggal. Kebanyakan wisatawan menginginkan paket wisata yang menggabungkan dua propinsi yaitu berawal kota Pekanbaru dan berakhir di Kota Padang. Sedangkan paket travel yang tersedia di Kota pekanbaru kebanyakan hanya di lingkungan Kota Pekanbaru sehingga menimbulkan kurang ketertarikannya bagi wisatawan.

3. Tanggapan faktor-faktor penarik kepariwisataan wisatawan asal Malaysia yang terdiri aksesibilitas, ketersediaan jasa atau service, budaya, stabilitas politik dan keamanan serta ketersediaanya atraksi wisata dinilai cukup tinggi dalam mempengaruhi tingkat keputusan berkunjung ke Kota Pekanbaru yaitu sebesar 64\%. Hal tersebut menunjukan bahwa faktor-faktor penarik kepariwisataan wisatawan asal Malaysia dapat di jadikan sebagai alat ukur untuk menyusun strategi pemasaran pariwisata Pemerintah Kota Pekanbaru.

\subsection{Rekomendasi}

Berdasarkan hasil penelitian yang dilakukan, maka penulis merekomendasikan hal-hal berikut:

1. Rendahnya persepsi wisatawan asal Malaysia terhadap stabilitas politik dan keamanan perlu mendapatkan perhatian dari Pemerintah. Pemerintah Kota Pekanbaru harus memperbaiki sistem manajemen pengunjung dengan cara meningkatan keselamatan pengunjung, dapat dilakukan dengan meningkatkan kegiatan patroli, monitoring pengunjung terutama pada saat-saat ramai pengunjung, penyediaaan sarana pengawasan, membuat standar keselamatan tempat wisata, membentuk regu penolong dan emergency respond.

2. Pemerintah Kota Pekanbaru perlu kerjasama yang lebih erat dengan stakeholder pariwisata lokal maupun stakeholder pariwisata asing misalnya hotel, travel agent, dan media masa maupun media elektronik dalam mengelola informasi pariwisata sehingga berita-berita pariwisata tentang stabilitas politik dan keamanan yang bersifat negatif dapat diatasi.

3. Rendahnya persepsi wisatawan asal Malaysia terhadap faktor budaya, hal ini harus di antisipasi. Sebaiknya 
pemerintah Kota Pekanbaru terus berupaya mengelola produk wisata dengan cara penataan obyek wisata dan atraksi wisata yang menarik. Tindakan yang harus dilakukan adalah menetapkan obyek dan atraksi wisata sebagai obyek wisata inti (core attraction) dan pendukungnya (supporting attraction). Jarak antara obyek inti dan pendukungnya dekat sehingga dapat dikunjungi kurang dari satu hari dan rutenya dirancang berbentuk lingkaran (cycle) sehingga dapat kembali ke tempat keberangkatan semula, serta pengembangan usaha souvenirs khas di kawasan objek-objek wisata.

4. Perlu bekerjasama antara pemerintah Kota Pekanbaru dengan biro perjalanan asing dan biro perjalanan lokal dalam mengelola penawaran paket wisata alternatif maupun paket wisata kombinasi terhadap wisatawan.

5. Faktor Harga dapat berperan dalam upaya mendukung wisatawan untuk berkunjung. Tanggapan mengenai faktor harga terhadap keputusan berkunjung ke Kota Pekanbaru memperoleh skor yang terendah di bandingkan variabel yang lainnya. Hendaknya pihak manajemen objek wisata, travel agen maupun penyedia fasilitas jasa seperti hotel dan rumah makan di Kota Pekanbaru memperhatikan secara cermat faktor Harga paket wisata, dan cinderamata. Misalnya menyesuaikan harga dengan kualitas pelayananan yang diberikan kepada wisatawan.

\section{DAFTAR PUSTAKA}

Arikunto, Suharsimi (2009), Prosedur Penelitian Suatu Pendekatan Praktek, Jakarta: Rineka Cipta.

Ariyanto,( 2005). Ekonomi Pariwisata Jakarta: $\quad$ online\} tersedia: http://www.geocities.com/ariyantoeks/h ome.htm \{23 April 2011\}.

Bagus Rai Utama, I Gusti. (2010). Persepsi dan Faktor-Faktor yang Mempengaruhi Wisatawan Berkunjung Ke Kebun Raya (Bontanical Garden) Eka Karya Bali. $\quad$ online $\quad$ tersedia: http://raiutama.multiply.com/?\&=\&pre view=\&item_id=207\&page_start $=320$ $\{25$ Juni 2011\}.

Dinas Kebudayaaan dan Pariwisata Propinsi Riau (2011).

Esti, Caporaningsih dan Janianton Damanik (2008). Faktor-Faktor yang mempenga-ruhi pola pergerakan wisatawan di Kabupaten Pacitan. Jurnal Kepariwisataan Indonesia Vol. 3, No. 2, Juni 2008 ISSN 1907-9419.

Hasan, Ali. (2008). Marketing. Jakarta: Medprees (Anggota IKPI).

Harun Al Rasyid. (2001). Teknik penarikan sempel dan penyusunan skala. Program studi ilmu sosial-bidang kajian utama sosiolo Antropologi-program Pasca sarjana UNPAD.

Husein, Umar. (2008). Metedologi Penelitian untuk skripsi dan tesis, Jakarta: PT. Raja Grafindo Persada.

Horner, Susan dan John Swarbrooke (2007). Consumer Behaviour inTourism, Second edition.. Elsevier Ltd.

Ismayanti. (2010). Pengantar Pariwisata. Jakarta. PT Gramedia Widiasarana Indonesia.

Kuncoro, M. (2003). Metode Riset untuk Bisnis dan Ekonomi. Jakarta. Erlangga.

Kusmayadi. (2004). Statistika Pariwisata. Jakarta. PT. Gramedia Pustaka Utama.

Kotler, Keller and Kevin Lane. (2009). Managemen Pemasaran. Indonesia. PT. Jaya Cemerlang.

Lili Adi Wibowo , 2008. Usaha Jasa Pariwisata. $\quad$ online $\}$ tersedia: file.upi.edu/...WISATA/.../Usaha Jasa Pariwisata@Lili_Adi_Wibowo.pdf. $\{23$ April 2011\}.

Mangkunegara, AA Anwar Prabu. (2009). Prilaku Konsumen. Bandung. Reflika. Aditama. ( Anggota KPI).

Marpaung, Happy dan Herman Bahar, (2002). Pengantar

Pariwisata, Bandung:Alfabeta.

Morrisan. (2007), Prilaku Komunikasi Pemasaran Terpadu. Jakarta: Ramdina Prakarsa.

Mulyana, indra, (2009). Pasar Pariwisata. \{online $\quad$ tersedia: http://www.wisataciamis.com/2009/06/ pasara-pariwisata.html. $\{5$ Mei 2011\}.

Narbuko, Cholid dan Drs. H. Abu acmadi. (2001). Metodelogi Penelitian. Bandung: Alfabeta. 
Pavule, Giva .(2006). International Tourism Market for camping Sites in Latvia. Bornemouth University. Hochschule Heilbronn.

Pitana, I Gede dan Gayatri G Putu. (2005). Sosiologi Pariwisata.Yogyakarta: CV. Andi Offset.

Purnomo, Cahya. (2010). Persepsi Wisatawan Mancanegara terhadap mutu produk di Kabupaten Bantul. Efektif jurnal bisnis dan ekonomi, Vol. 1, No. 1, Juni 2010, 43-53. Akademi Maritim Yogyakarta.

Rahajeng, Anggi. (2008). Analisis Faktor keputusan berwisata budaya, sejarah, dan Alam Yogyakarta: Persepsi Wisatawan Domestik. Jurnal Ekonomi Pembangunan, Vol 13, 1 April 2008, hal 33-49.

Uma Sakaran, (2000). Research Methods for Bisnis. $3^{\text {rd }}$ Edition. New York: John Willey and Sons.

Schiffman, Leon G. dan Leslie Lazar Kanuk. 2007. Consumer Behavior $9^{\text {th }}$ Edition. Person Internasional Edition.

Sugiono. (2008). Metode Penelitian Bisnis. Bandung: Alfabeta.

Sugiono. (2009). Metode Penelitian Bisnis. Bandung: Alfabeta.

Suwantoro, Gamal (2002). Dasar-Dasar Pariwisata. Yogyakarta: Andi. Offset.

Swasta, Basu dan T Hani Handoko. 2000. Manajemen Pemasaran: Analisa dan Perilaku Konsumen. Yogyakarta: BPFE.

Warpani, Suawardhoko P. (2007). Pariwisata dalam Tata Ruang Wilayah.Bandung: ITB.

Soebiyantoro, Ugy. (2009). Pengaruh ketersediaan Sarana Prasarana Transportasi terhadap kepuasan wisatawan. Jurnal Manajemen Pemasaran, Vol. 4, No. 1, April 2009: 16-22. Fakultas Ekonomi UNP Surabaya. Program Doktorat Ilmu Managemen Universitas Brawijaya. Malang.

Undang-Undang Republik Indonesia Nomor 10 Tahun 2009, Tentang kepariwisataan.

Departemen Kebudayaan dan Pariwisata Republik Indonesia.

Vellas, Francois and Lionel Becherel. (2008). Pemasaran Pariwisata Internasional. Jakarta: Yayasan Obor Indonesia.
Wahab, Salah. (2003). Manajemen Kepariwisataan. Jakarta: PT. Perca.

Yoeti, Oka A, Drs. BA. (1997). Perencanaan dan Pengembangan Pariwisata. Jakarta: Pradya Paramita.

Yoeti, Oka A, Drs. BA. (1990.). Pemasaran Pariwisata. Pradya Paramita. Jakarta.

Zikmund, William G.(2000). Business Research Methods. $6^{\square h}$ Edition.

Website.

www. Indonesia.html www.World Tourism Organization 2011

www. Riau.go.id

www. Bps Riau dalam angka 2010

www.riaubisnis.com

http://www.Pekanbaruriau.com

www.go Bengkalis.com

www.wikimedia.com 